\title{
FOTOGRAFIA, MEMÓRIA E PATRIMÔNIO INDUSTRIAL: PARA SABER DO FRIGORÍFICO ANGLO DE PELOTAS/BRASIL E DE FRAY BENTOS/URUGUAI ${ }^{1}$
} PHOTOGRAPHY, MEMORY AND INDUSTRIAL HERITAGE: TO KNOW ABOUT FRIGORÍFICO ANGLO FROM PELOTAS/BRAZIL AND THE FRAY BENTOS/URUGUAY

\begin{abstract}
Resumo: Apresentam-se resultados, discussão e conclusões parciais advindas do desenvolvimento de dois anos do projeto título deste relatório, bem como a relação e continuidade em outro projeto em andamento, desenvolvido como pesquisa de mestrado. Ambos, imbricados no mesmo campo de observação, discutem relações entre as memórias de ex-trabalhadores e a identificação dos setores de trabalho da extinta unidade fabril em Pelotas, em um estudo comparativo com o caso da unidade fabril de Fray Bentos, hoje já declarada pela UNESCO como patrimônio cultural da humanidade, na categoria Paisagem Cultural. O estudo comparativo permitiu observar o processo de patrimonialização das duas fábricas e a trajetória de diluição dos referenciais memoriais na unidade brasileira. Ainda, considera-se o emprego da fotografia como recurso para apreensão de vestígios aplicáveis as duas categorias fundamentais ao trabalho: memória social e patrimônio industrial e como recurso para apreender os vestígios de um urbano preterido em prol da vida citadina não fabril. Por fim, o relatório registra a trajetória do Frigorífico Anglo de Pelotas e a sua conversão de unidade fabril para patrimônio industrial, ressalta-o como protagonista de uma paisagem urbana que se moldou à sua presença e se propõe a refletir sobre a cidade operária que se desvela pela
\end{abstract}

\footnotetext{
1 Projeto de pesquisa contemplado com auxílio no Edital CHAMADA UNIVERSAL - MCTI/CNPq No $14 / 2013$

2 Doutora em História, Professora do Programa de Pós-Graduação em Memória Social e Patrimônio Cultural, Universidade Federal de Pelotas, RS, Brasil. E-mail: fmichelon.ufpel@gmail.com

${ }^{3}$ Mestrando no Programa de Pós-Graduação em Memória Social e Patrimônio Cultural. Universidade Federal de Pelotas, RS, Brasil. E-mail: ubirajara.cruz@gmail.com
} 
memória dos ex-trabalhadores. É um estudo que se desenvolve a partir de duas categorias de análise: memória social e patrimônio industrial.

Palavras-chave: Fotografia. Memória Social. Patrimônio industrial. Frigorífico Anglo.

Abstract: This paper presents results, discussion and conclusions originated from the development of the project in the title of this report along with its relation and continuity in another ongoing project developed as a Masters research project. Both, inserted in the same field of observation, discuss relations between former workers' memories and the identification of working sectors in the extinct factory in Pelotas, in a comparative study with the factory Fray Bentos, which has been listed as Cultural Heritage by UNESCO in the category Cultural Landscape. The comparative study allowed the observation of the development of the heritage process of both factories and the trajectory of dilution of memory references in the Brazilian unit. Also, it considers the use of photography as a resource to capture applicable traces of two categories vital to this work: social memory and industrial heritage as well as a resource to capture traces of an urban scenery neglected in favor of a non-industrial city life. Finally, the report registers the trajectory of the Frigorífico Anglo from Pelotas and its conversion from a factory into industrial heritage, highlighting it as the protagonist of an urban landscape which was shaped to its presence, It also proposes some reflection upon the working city which is revealed through the former workers' memories. This study was carried out based on two categories of analysis: social memory and industrial heritage.

Keywords: Photography. Memory. Industrial heritage. Frigorífico Anglo.

\section{INTRODUÇÃO}

Na sua proposição inicial, o projeto, escopo deste relatório parcial, partia da constatação preliminar de que o registro fotográfico das formas de trabalho já se fazia observar desde o século XIX, consolidando-se em significativas experiências no século $\mathrm{XX}$, que permitiram ilustrar para o futuro os muitos sujeitos da história do trabalho, os seus fazeres e as formas de adaptação às transformações tecnológicas que suplantaram os espaços e práticas de ofícios ou lugares extintos. Do mesmo modo, se buscava a relação memorial passível de ser plasmada no caso das unidades fabris dos Frigoríficos Anglo da cidade de Pelotas e da cidade uruguaia de Fray Bentos. Da segunda se tinha o registro de dois arquivos fotográficos disponíveis: o primeiro 
pertencente ao Museo de La Revolución Industrial e o segundo de posse do Archivo Nacional de la Imagen del Sodre. Na ocasião da proposição deste trabalho, o primeiro estava parcialmente identificado, enquanto o segundo encontrava-se em fase de digitalização. Por consulta prévia, sabia-se que em ambos havia registro das sucessivas fases da indústria da carne no Uruguai. Tal situação era o contraponto para a unidade fabril da cidade de Pelotas, ao sul do Rio Grande do Sul. Essa segunda unidade do Frigorífico Anglo no Brasil, foi instalada em 1943, apresentando-se em situação contrastante com o caso uruguaio. Inicialmente, consideradou-se a possibilidade de que a documentação fosse escassa e se encontrasse espargida. O desenvolvimento do projeto indicou que não havia documentação arquivística dessa unidade. As fotografias localizadas no levantamento prévio ao projeto, indicavam elementos a serem verificados e para os quais se demandavam depoimentos, única fonte que se apresentava como possível diante do vácuo gerado pela inexistência de outros suportes documentais. Também, no momento da proposição do projeto, parecia suficiente para compreender o processo de esquecimento do complexo pelotense, a comparação entre os casos de Fray Bentos e de Pelotas. No entanto, em 2015 o complexo fabril uruguaio tornou-se patrimônio da humanidade e acentuaram-se as diferenças e o sentido de esvanecimento que se dava pelo atual uso do extinto Anglo de Pelotas, como fator decorrente do progressivo esvaziamento de vestígios do passado desse lugar. No período e antecedendo o ingresso na lista da UNESCO, foi realizada mais uma visita técnica ${ }^{4}$ ao Sistema Patrimonial do Anglo na cidade uruguaia de Fray Bentos, além da anterior realizada em 2013. Foram comparadas as semelhanças e diferenças entre os dois grandes conjuntos, levantadas anteriormente nas paisagens de ambos os lugares.

Se por um lado entendia-se que, ainda que alterado e parcialmente destruído, o que sobrou do Frigorífico Anglo de Pelotas, no local hoje ocupado pela Reitoria e Faculdades da Universidade Federal de Pelotas, tinha grande potencial evocativo para o meio centenário de história dessa fábrica, por outro, admitia-se que esta referência demandava um lugar físico para marcar a informação do primeiro uso. Tendo sido o objetivo geral do projeto observar como as fotografias localizadas tanto otimizavam como promoviam o processo memorial, entendeu-se que este espaço de memória deveria conter, sobretudo, fotografias. Assim, este relatório também apresenta o projeto, implantação e uso do Memorial do Anglo na extinta unidade pelotense. 0 Memorial, assim constituído, passou a ser o locus de ativação do processo memorial. Também era objetivo analisar as possibilidades de restituição do valor patrimonial a

\footnotetext{
${ }^{4}$ Em 2013, foi feita a primeira visita técnica ao Anglo de Fray Bentos, na qual se acordou o trabalho em cooperação com a direção do Museo de la Revolución Industrial.
} 
esse local por meio do encontro entre as fotografias do passado com os relatos de quem ali trabalhou. Advoga-se, por meio dos resultados obtidos, que essas possibilidades foram constatadas, sob vieses e aspectos inauditos. A trajetória de meio século de uso contínuo como frigorífico, seguida de uma década de abandono e desde 2007, com nova ocupação, metaforiza, na conclusão desse trabalho, o processo de esvaziamento de sentidos de passado. O presente se impõe e o fluxo das atividades que ocupam o lugar não requisitam a sua trajetória. No entanto, é verificável o poder de ressignificação que a fotografia gerada durante a existência do complexo antes do seu uso e de complexos equivalentes, possui. Igualmente, esse fato foi possível de ser observado no Memorial. Assim, esse relatório apresenta o desenvolvimento do projeto em relação aos objetivos iniciais e os resultados obtidos, quando se optou pela implantação do Memorial, em espaço físico e virtual. Antecipa-se que o principal resultado da pesquisa foi o impacto na política de proteção ao patrimônio cultural da UFPel, para a qual outro projeto, este desenvolvido como pesquisa de mestrado iniciada em 2014, também vem impactando positivamente. Ao fim, apresentam-se todos os trabalhos decorrentes da pesquisa e que continuarão a serem desenvolvidos de 2016 até 2019, incluindo a formação de recursos humanos, a contribuição para uma nova linha de pesquisa no Programa de Pós-Graduação em Memória Social e Patrimônio Cultural, a proposição de cooperação científica com a Universidade de Sevilha e o trabalho de inserção social com o estabelecimento de um acordo de cooperação entre esse PPG e a Secretaria Municipal de Educação, para desenvolvimento de uma proposta de educação patrimonial, inicialmente formulada no estudo do patrimônio industrial.

O relatório desenvolve-se apresentando, inicialmente, o objeto da pesquisa, após fundamenta-se o escopo na relação memorial entre fotografia e lugares de trabalho para depois partir dos objetivos inicialmente arrolados, relatando os métodos e analisando os resultados obtidos. São justificados os novos rumos, porque foram diversos, e observados os motivos que os determinaram. Por fim, apresentam-se as metas atingidas, bem como se detalham os desdobramentos já indicados no parágrafo anterior e as metas a serem atingidas até outubro de 2016.

Inicia-se circunstanciando o tema da pesquisa.

\section{CARACTERIZAÇÃO DO TEMA E OBJETO DA PESQUISA}

O remanescente do Frigorífico Anglo de Pelotas, que iniciou a funcionar no ano de 1943, localiza-se em uma região às margens do Canal São Gonçalo que, na altura do seu surgimento, não era habitada. A rua, ainda hoje chamada Gomes Carneiro, 
estendia-se quase sem curvas da área central da cidade até os portões da fábrica e foi sendo ao longo da trajetória de 70 anos, urbanizada. O complexo tinha, como ainda tem, o número 1 e surgiram as vilas que hoje rodeiam o Campus da Universidade Federal de Pelotas (UFPel), instalada na área do extinto frigorífico a partir de 2007. $\mathrm{Na}$ Figura 1 é visível a localização descrita e a relação do complexo com a zona portuária da cidade, dimensionando os impactos da sua instalação na cidade dos anos de 1940. As obras de construção do frigorífico duraram, inicialmente, dois anos. No entanto, sabe-se pelos depoimentos, que as ampliações e modificações no complexo fabril ocorreram durante toda a sua existência. A mais importante foi a mudança na área do abate, ocorrida em meados dos anos de 1970. Matérias publicadas no ano da inauguração da fábrica, indicam ter sido o maior empreendimento industrial ocorrido na cidade até aquele momento, tal como se lê no jornal Diário Popular, que diz ser esse frigorífico "[...] a maior realização industrial desta cidade" (p. 8).

Figura 1 - Imagem com localização do Campus Anglo UFPel

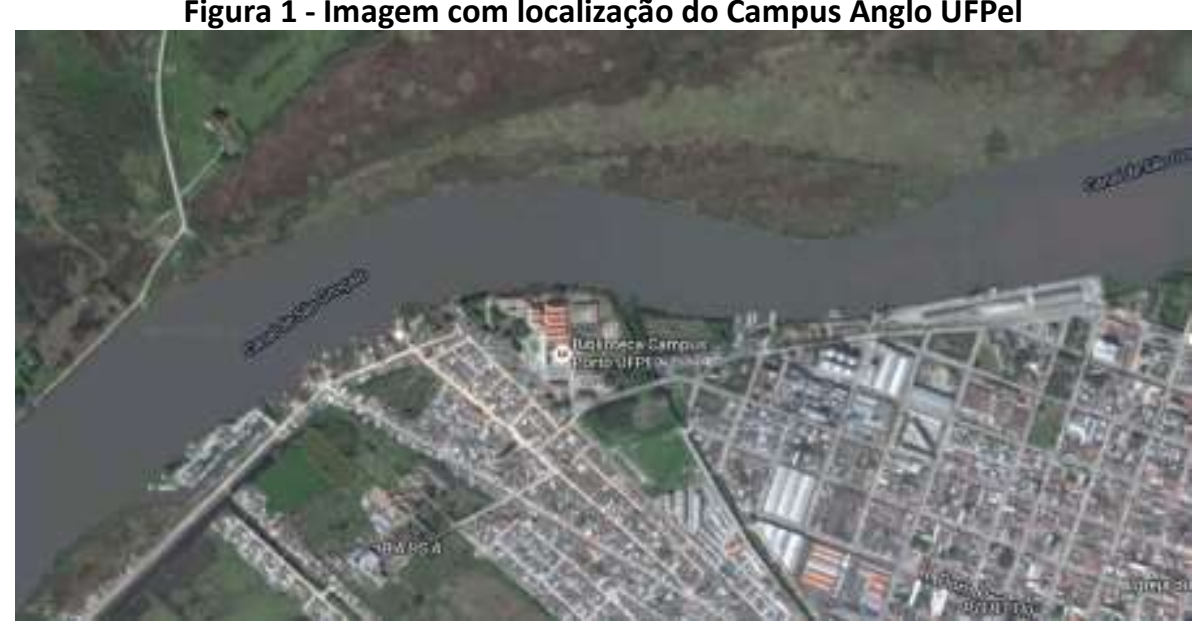

Fonte: Google Earth/ maps

Não obstante ter se encontrado fotografias que respaldassem os relatos de extrabalhadores, sobre como nos inícios e finais de jornadas de trabalho a rua era tomada por uma multidão de operários que percorria o longo trecho entre a fábrica e o centro da cidade, é crível a ocorrência, se levada em comparação e como referência as fotos do Frigorífico Swift de Berisso, Argentina (Fig. 2) e do Anglo del Uruguay, em Fray Bentos (Fig. 3) que, entre outras, ilustram o contingente de pessoas que circulavam nesses lugares. Sobretudo, o melhor recurso que materializa os relatos de extrabalhadores, tem sido as fotografias do complexo de Fray Bentos, que indicam aspectos próprios desta indústria e, sobretudo, desses dois frigoríficos. Fray Benstos é, hoje, Patrimônio Mundial, da UNESCO reconhecido na categoria de "Paisaje Cultural Industrial Fray Bentos" e a instrução do processo contendo o pedido para esta inscrição, beneficiou-se dos muitos documentos existentes. Cidades diferentes com trajetórias diversas, Pelotas no sul do Rio Grande do Sul, Brasil e Fray Bentos, às 
margens do rio Uruguai, incitam verificar o impacto que tiveram enquanto ativas e após, quando foram fechadas.

Figura 2 - Saída de trabalho do Frigorífico Swift, Berisso, Argentina

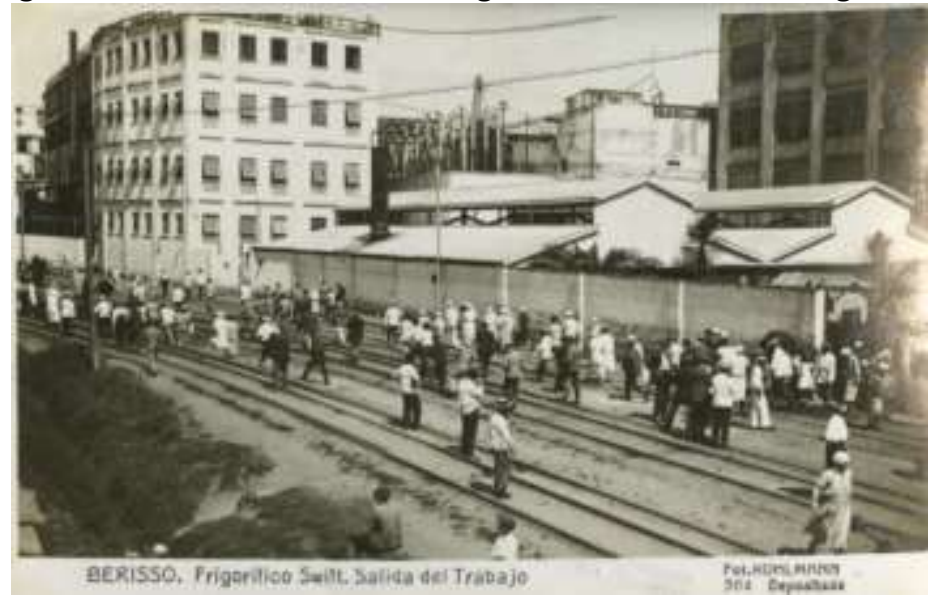

Fonte: Archivo General de la Nación, Buenos Aires, Argentina

Figura 3 - Troca de turno no Frigorífico Anglo del Uruguay, Fray Bentos

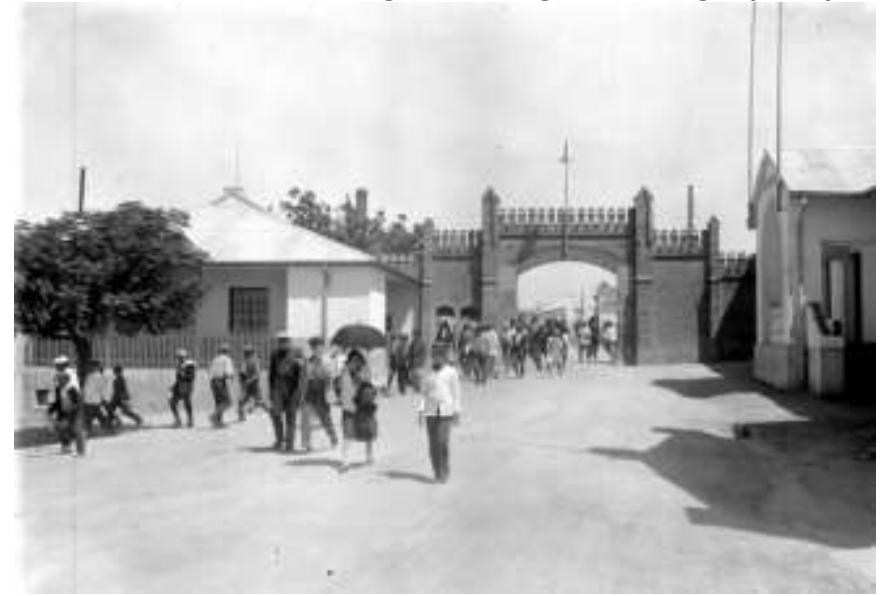

Fonte: Archivo Nacional de la Imagen del Sodre, Montevideo, Uruguay

Ambas, assim como tantas histórias equivalentes e perdidas, podem vir a ser reconhecidas como protagonista de uma paisagem urbana que se moldou a sua presença e podem revelar a cidade operária que se mantém na memória dos extrabalhadores. Com esta possibilidade, a de encontrar o passado de uma cidade encoberta, a fotografia mostrou-se apta para apreender os vestígios de um ambiente fabril, cuja evidência são tais remanescentes industriais.

\section{A TRAJETÓRIA DO FRIGORÍFICO ANGLO EM PELOTAS}

Os antecedentes do Frigorífico Anglo estão em 1918, quando a União dos Criadores do Rio Grande do Sul, a Associação Comercial de Pelotas e outros 
investidores decidiram criar um frigorífico em Pelotas, conforme concluiu o economista Eugênio Lagemann (1985) ao estudar a falência do Banco Pelotense. Foi, justamente, esse banco, o principal acionista a custear o local para o empreendimento, onde antes se localizava a charqueada de Alfredo Braga, herdada de Felisberto Gonçalves Braga, ambos charqueadores. O então prefeito, Cypriano Rodrigues Barcellos, em 1914, comprou o terreno para fazer o Asseio Público e um frigorífico que fosse capaz de dar vazão à indústria da carne, economia fundadora da cidade. Assim, teve início a história do complexo industrial da Companhia Frigorífico Rio Grande, o primeiro empreendimento de capital nacional no Rio Grande do Sul, que se arvorou na concorrência com os quatro frigoríficos estrangeiros instalados no Estado desde 1917 (JANKE, 2011, p. 46).

O empreendimento previa a instalação de um frigorífico completo, contendo um ramal ferroviário, um trapiche, oficinas, depósitos e câmaras frias, constituindo uma fábrica grande para os padrões da época (MICHELON, 2012), com capacidade para abater quinhentas reses por dia e com condições para conservar frutas, laticínios e demais produtos perecíveis. Problemas de diferentes ordens, sobretudo econômicas, resultariam na venda do complexo para o grupo inglês Vestey Brothers, em 1921, pouco depois de concluída a obra. Em matéria publicada no Almanach de Pelotas (1921, p. 291-293) informa-se que a construção do frigorífico foi feita por dois construtores de Buenos Aires, Scott e Hume, responsáveis pela execução de vários outros frigoríficos na Argentina. Descreve-se o abate e o processamento da carne correspondendo a um frigorífico dentro dos padrões que o capital estrangeiro estava utilizando nas suas unidades o que equivalia ser exemplo da técnica e tecnologia mais atual em abate e refrigeração de carnes. Em 1920, o frigorífico abateu 2.949 animais, dos quais 1.034 foram empregados na produção de charque. O restante, diz a matéria, foi exportado para a Inglaterra (17 dez. 1943, p. 8).

Em 14 de março de 1921, foi lavrada a escritura e, em novembro do mesmo ano, a fábrica começou a funcionar com o nome The Rio Grande Meat Company. Em 1924 mudou o nome para Frigorífico Anglo de Pelotas, já em funcionamento parcial, que se manteve penosamente até 1926, quando foi desativado. Constatou-se, em pesquisa bibliográfica, esse mesmo procedimento em unidades na Argentina, ou seja, os grupos estrangeiros adquiriam fábricas e as desativavam até momento oportuno. Tais empreendimentos implicavam na compra de unidades já instaladas em lugares que atendiam quesitos básicos: proximidade com um porto marítimo, possibilidade de numerosa mão de obra no entorno e acesso à matéria prima. As aquisições garantiam que em momentos de farta produção e exportação, houvesse a possibilidade de ativar rapidamente essas unidades. Enquanto essa demanda não surgia, o grupo mantinha a 
unidade desativada, o que no caso pelotense foram 15 anos. Só em 1942, com a demanda de alimentos para a Europa, durante a Segunda Guerra Mundial, começaram as obras de ampliação e adequação do frigorífico, para torná-lo uma unidade produtiva complementar aos demais já existentes no Uruguai, Argentina e, mesmo, no Brasil. Em 17 de dezembro de 1943, a unidade foi inaugurada, consistindo na maior realização industrial da cidade, conforme notícia publicada no jornal Diário Popular ${ }^{5}$. Ao longo dos anos, novos prédios foram construídos, modernizados e adaptados para atender as exigências da inspeção sanitária e atender aos novos processamentos e produtos, até que em meados dos anos 1970 a disputa pelo mercado da carne, a insurgência dos industrialistas nacionais contra os trustes estrangeiros e as exigências na qualificação da industrialização da carne, promoveram o declínio do investimento estrangeiro no Brasil, momento em que algumas empresas estrangeiras começaram a deixar o país como resposta ao crescimento do capital nacional no setor.

No final dos anos de 1980 a produção do Anglo vinha diminuindo de tal modo que a fábrica foi sendo desativada. De acordo com o depoimento do ex-trabalhador Jesus Rottman ${ }^{6}$, mantinha-se, apenas, a industrialização de carne, de seus derivados, de frutas e de legumes. Nesse período, o Anglo foi fechando todos os seus escritórios no Rio Grande do Sul. O grupo inglês Vestey Brothers, detentor da bandeira Anglo, encerrou suas atividades vendendo suas unidades daquele momento até 1993 . O Frigorífico Anglo de Pelotas foi desativado em 1991 (MICHELON, 2012, p. 62), embora, de acordo com o depoente supracitado, em 1990 cessaram todas as atividades, ficando para o ano de1991, o desmanche dos setores para venda ou transferência de material para a unidade de Barretos, em São Paulo. Supõe-se que o arquivo da fábrica tenha sido enviado à Barretos na ocasião. Fez-se tentativas para localizar a documentação, porém, a notícia mais crível é de que quando Anglo de Barretos foi vendida para o grupo JBS, dono da Friboi, a documentação foi evadida do Brasil. Em contato com o grupo Vestey Brothers, a informação conseguida nega a existência dos documentos das unidades já encerradas. Levantou-se a hipótese de que a documentação brasileira se

\footnotetext{
${ }^{5}$ Inaugura-se hoje o Frigorífico Anglo. Diário Popular. Pelotas, 17 dez. 1943. p. 8.

${ }^{6}$ Depoimento do Sr. Jesus Miguel Rottman, administrador geral, em 28 jul. 2015. Esta mesma informação foi apresentada pelo Sr. Silvio Cavalheiro Paulo em 17 out. 2014. Os depoimentos deste ex-trabalhador foram retomados em entrevistas sucessivas dado o fato de que trabalhou no Anglo Pelotas de 1957 a 1987. Nos anos seguintes, já aposentado, prestou serviços para a empresa na qualidade de consultor. Acompanhou o encerramento da empresa em 1991 e Iniciou como aprendiz e especializou-se na manutenção das máquinas, razão pela qual conhecia detalhadamente todos os setores. Visitou o Campus Porto, assim inicialmente chamado o complexo ocupado pela Universidade Federal de Pelotas, em companhia dos autores da pesquisa várias vezes e auxiliou a compreender como a intervenção no segundo piso descaracterizou a planta original da sala do abate. Dotado de excelente memória, contribui para a identificação dos setores ao longo do prédio e registrou o período no qual houve a alteração da sala de abate para adequar-se às exigências das normas de exportação. Ainda, no presente deste relatório, contribui com a equipe na indicação de depoentes.
} 
encontraria, em partes, no arquivo uruguaio de Fray Bentos. A verificação deverá ser in loco. O acordo de cooperação entre os pesquisadores brasileiros e uruguaios, que franqueia a pesquisa no acervo do Museo de La Revolución Industrial ${ }^{7}$.

No período do fechamento, que foi processual, o complexo fabril passou por um período de esvaziamento. As máquinas e equipamentos ainda não obsoletos foram encaminhados para as unidade de Curupi, Goiânia e de Barretos ${ }^{8}$. Os documentos saíram da fábrica e tomaram rumos desconhecidos ou supostamente foram para Barretos, como já dito anteriormente. Parte do maquinário e de instalações mecânicas sem uso foi vendida como sucata. Outra parte, como os compressores, mesas rolantes, caldeiras e máquinas aproveitáveis para a planta fabril depois que o Anglo foi adquirido por uma outra empresa, foi utilizada parcialmente por um curto período.

No final de 2005, a Fundação de Apoio Universitário Símon Bolívar comprou da Casarin Empreendimentos o complexo fabril inativado e doou parte das construções para a Universidade Federal de Pelotas que, em 2006, iniciou as obras de adequação dos edifícios para receber seu novo campus universitário. Na ocasião, o complexo já estava protegido e constava no Plano Diretor da Cidade de Pelotas bem como estava listado no inventário do Patrimônio Cultural com proteção nível 2.

A despeito da proteção, as obras para adaptação das instalações em salas de aula, laboratórios, biblioteca e demais dependências acadêmicas e administrativas, alteraram significativamente a aparência das edificações. Algumas partes de máquinas, que ainda restavam nos prédios, foram retiradas de seus locais e desmanchadas. Na Figura4 vê-se, em documentação do ano em que a fábrica foi adquirida pela UFPel, uma vista da casa das máquinas, nas quais aparecem as estruturas dos compressores. Em documento realizado na visita técnica à Fray Bentos (Fig.5), vê-se a casa de máquinas completa. Junto ao campus, havia o projeto de um shopping center, à esquerda de quem entra no portão, projeto este que não se concretizou. No entanto, a empreiteira que adquiriu o complexo derrubou parte do prédio das conservas. Tal como consta na documentação (Fig.6) sabe-se o tamanho das salas e essa pesquisa logrou identificar as funções que tinham durante os anos 1980.

\footnotetext{
${ }^{7}$ Que ocorrerá quando houver recursos para que uma equipe do Brasil possa desenvolver o trabalho de levantamento dos documentos, haja vista que os documentos do Museo não estão inventariados e necessitam ser identificados e separados no momento da busca. Na visita prévia, o levantamento inicial indicou a necessidade de dois pesquisadores em tempo integral, por um período de 15 a 20 dias, para o levantamento das atas e das plantas. Outros documentos necessitam de tempo maior.
}

${ }^{8}$ Depoimento do Sr. Silvio Cavalheiro Paula, chefe da mecânica, em 29 jan. 2015. 


\section{Romith memória

Figura 4 - Casa das máquinas, Frigorífico Anglo de Pelotas

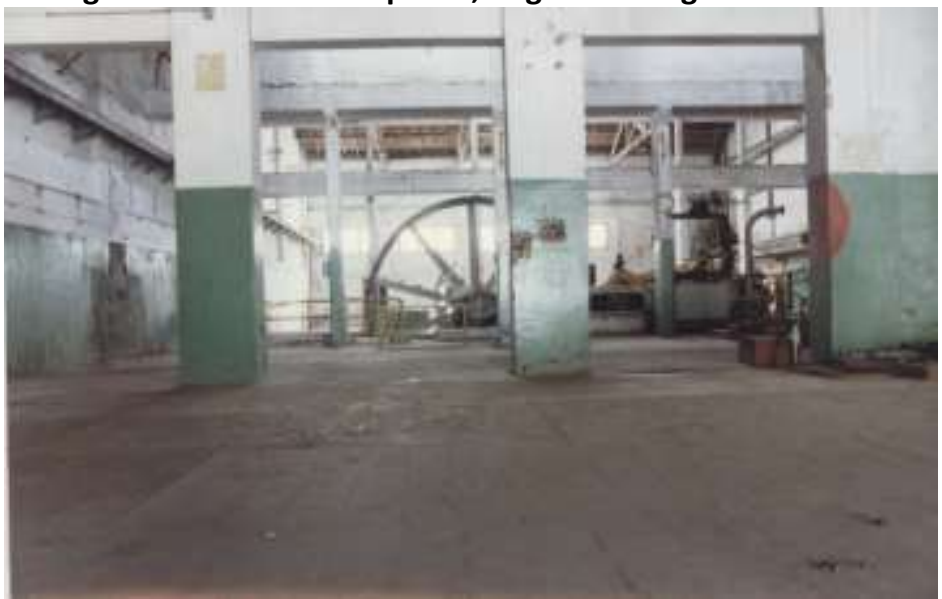

Fonte: Fotografia de Francisca Ferreira Michelon. Acervo da autora

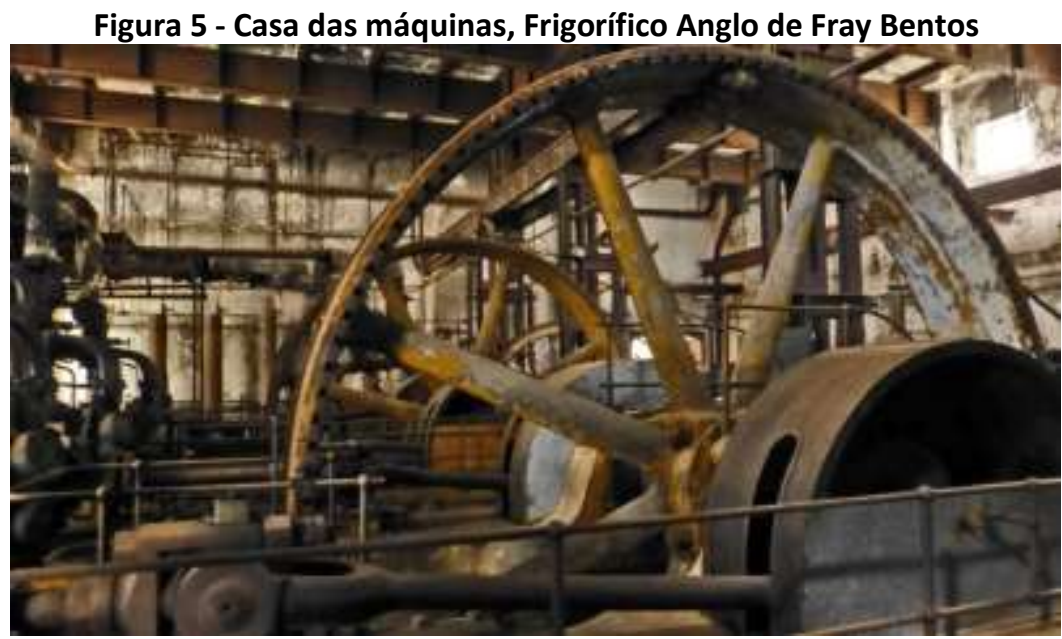

Fonte: Fotografia de Ubirajara Buddin Cruz. Acervo do autor

Figura 6 - Prédio onde funcionava a sessão de conservas

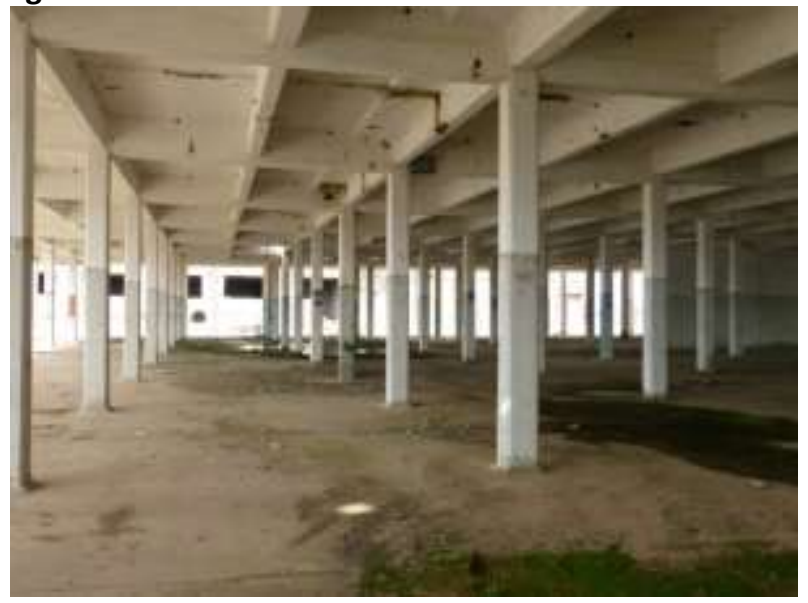

Fonte: Fotografia de Ubirajara Buddin Cruz. Acervo do autor 
Com as supressões ocorridas, faz-se ilegível o conjunto no todo. Alguns vestígios bastante significativos para este tipo de indústria, como os currais, a rampa de acesso à sala de abate, as câmaras frias, entre outros, foram descaracterizados ou destruídos. Entre os prédios colocados abaixo, do ponto de vista da memória coletiva, o mais importante foi o do setor de conservas, cujo frontão exibia o nome Anglo pintado em letras vermelhas e podia ser visto desde a ponte que demarca o limite dos municípios de Pelotas e de Rio Grande (Fig. 7). Antes de ser demolido, logo após a aquisição, a Universidade Federal de Pelotas substituiu o nome Anglo por UFPel (Fig. 8). Conforme as faculdades e a administração central foram se instalando no local, alguns projetos surgiram em prol da história da fábrica e em 2013, um estudo feito pelos autores desse trabalho levantou o patrimônio cultural da universidade, dando especial ênfase ao patrimônio industrial. Neste interim, o complexo do Anglo de Fray Bentos era apresentado para inscrição na lista do patrimônio mundial na categoria paisagem cultural.

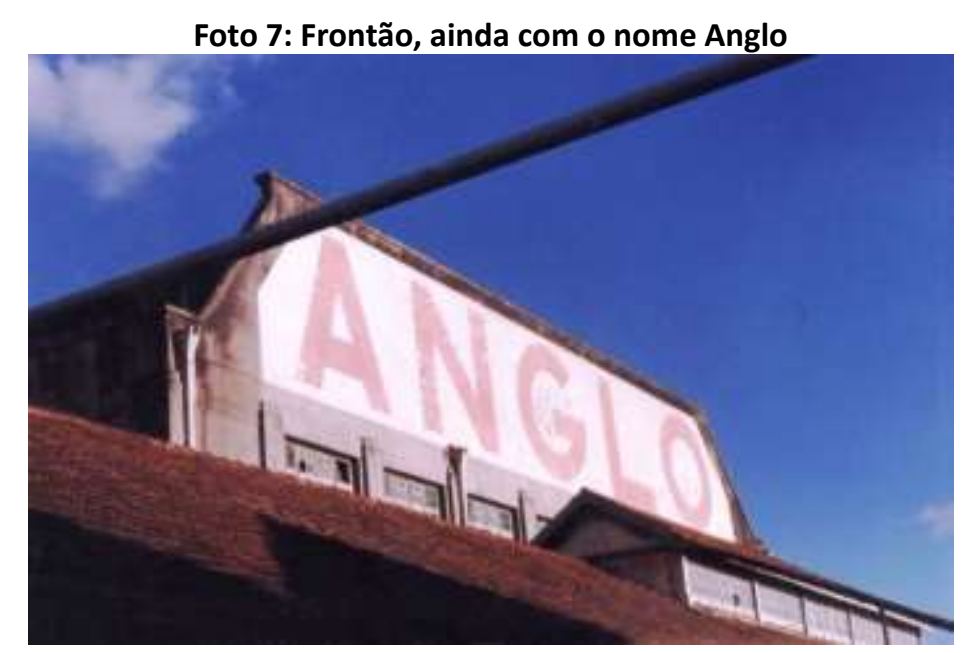

Fonte: Fotografia de Francisca Ferreira Michelon. Acervo da autora.

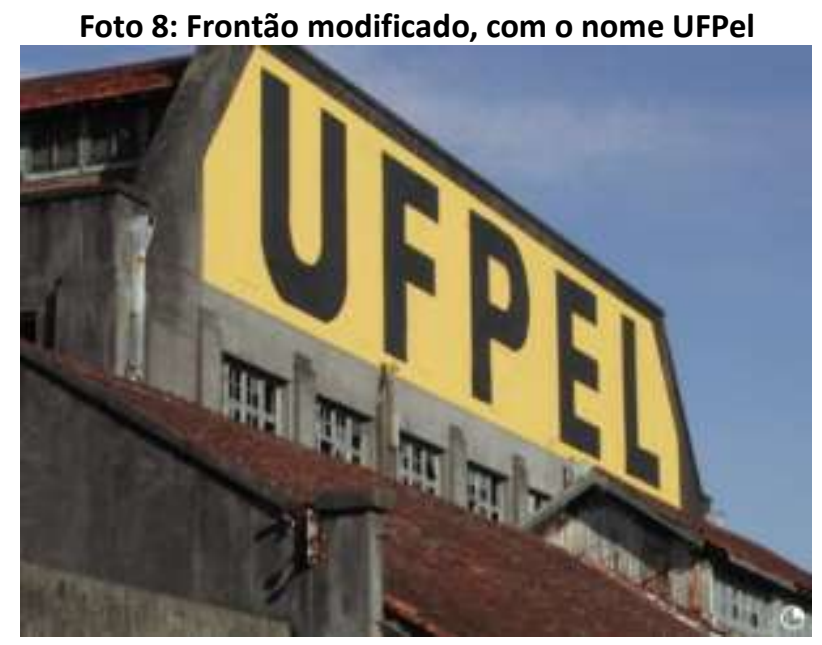

Fonte: Fotografia de Jesus Rottmann. Acervo do autor. 


\section{A TRAJETÓRIA DO FRIGORÍFICO ANGLO EM FRAY BENTOS}

Os antecedentes do Frigorífico Anglo de Fray Bentos datam de meados do século XIX, quando em 1865, na localidade que hoje é a cidade de Fray Bentos, a Liebig's Extract of Meat Company Limited (LEMCO), instalou-se para fabricar o extrato de carne em larga escala com a finalidade de ser exportado para Grã-Bretanha, Bélgica, Holanda, França, Dinamarca, Áustria, Espanha, Polônia, Rússia, Turquia e Estados Unidos (MICHELON, 2012, p. 21). Esse pequeno lugarejo, que não passava de uns poucos ranchos que somava algo em torno de duzentos habitantes passa, com sua fábrica, a ser conhecido como "O Colosso Liebig's", ou "A Cozinha do Mundo" (DOUREDJIAN, 2009, p. 21), constituindo uma unidade fabril autônoma que, ao contrário da região gaúcha, não era mais do que um extenso território vazio de urbanização. A LEMCO, além do extrato, produzia outros derivados de origem animal que se sucederam por muitas décadas e que, de acordo com revisão feita em estudo anterior (MICHELON, 2012, p. 21), culminou com o que seria o carro-chefe da indústria açougueira: a carne enlatada, ou corned beef (Fig. 9). O fim da Primeira Guerra Mundial significou para a Europa o início de uma crise que repercutiu na LEMCO. Além disso, segundo Douredjian, já fazia alguns anos que o mercado consumidor estava preferindo carne fresca e não conservada (2009, p. 27).

Figura 9- Corned beef Fray Bentos

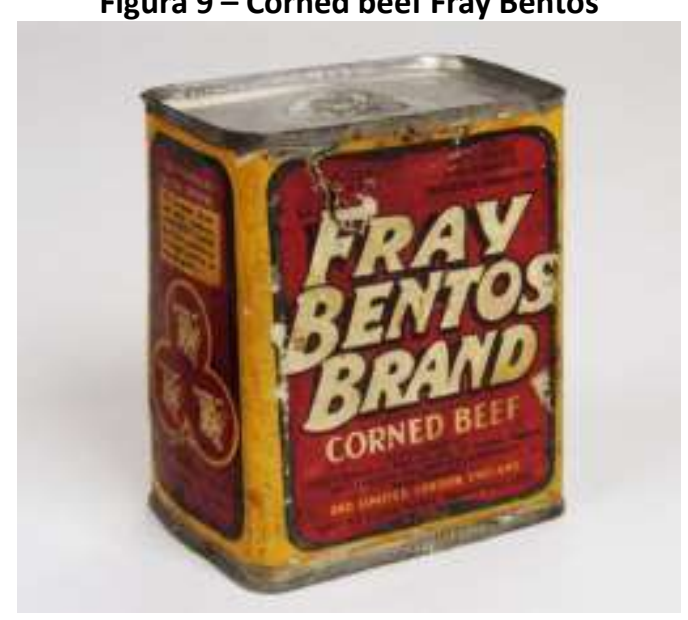

Fonte: Acervo do Museo de la Revolución Industrial, Fray Bentos, Uruguay

A LEMCO tinha como projeto edificar um frigorífico modelo, mas a crise da década de 1920 acabou falindo a fábrica que foi arrendada em 1924 pelo Grupo Vestey Brothers, que implantou o Anglo no Uruguai. O local que vivia da LEMCO passou, por consequência, a viver do e para o Anglo, em uma relação de dependência decorrente do volume produtivo que a fábrica alcançou no seu auge (CAMPODÓNICO, 2000, p. 100). Portanto, a fábrica uruguaia não só tem antecedentes mais distantes como mais determinantes e se iniciou o seu processo de fechamento mais cedo, foi quando já 
tinha longa história. Em dezembro de 1967, o Grupo Vestey Brothers anuncia ao Governo uruguaio que o Anglo deixaria o país e oferece a planta de Fray Bentos para venda, negócio que se concretizou formalmente no ano seguinte (MICHELON, 2012, p. 30) quando o Governo adquire a já obsoleta fábrica, criando o Frigorífico Nacional, Frigonal. No entanto, em 1969, a Inglaterra já não importava mais carnes do Uruguai em função da febre aftosa, determinando o fracasso do Frigonal como frigorífico. Restava manter-se como matadouro, função que sustentou penosamente até 1971, quando a falência integral fez-se irreversível. Se estenderia um penoso período de 15 anos até o ano de 1987, quando o complexo fabril e o Bairro Anglo são declarados Monumento Histórico Nacional. Era o início do processo que resultaria na criação do Museo de la Revolución Industrial, em 2005. Após, em 1987, foi ampliada a área tombada para que o conjunto passasse a se chamado Sistema Patrimonial Industrial Anglo. Foi, então, criada uma comissão de gestão, integrada pela Intendencia Departamental de Río Negro, a Comisión del Património Cultural de la Nación CPCNMEC e a Dirección Nacional de Ordenamiento Territorial. Em 27 de janeiro 2010, a comissão apresenta o Sistema, com o nome Paisaje Cultural Industrial Fray Bentos, para ser incluído na lista da UNESCO das declarações de Patrimônio Cultural da Humanidade. A UNESCO classificou o complexo como Projeto Piloto em 2011, fato que antecipou o processo que culminaria, em junho de 2014, no dossiê apresentado à UNESCO. Após algumas adequações, em julho de 2015, o processo é concluído com o Anglo, a cidade de Fray Bentos e sua paisagem industrial declarada Patrimônio Cultural da Humanidade.

\section{COMPARATIVO ENTRE AS UNIDADES DO ANGLO EM PELOTAS E FRAY}

\section{BENTOS}

A trajetória de ambos os frigoríficos, iniciadas em épocas e sob necessidades diferentes, é interseccionada por questões peculiares a essa indústria. Assertiva segura é de que tanto em uma localidade como na outra, essa indústria teve um importante ciclo produtivo que impactou o desenvolvimento econômico e social dos locais. No entanto, são cidades diferentes na origem. Pelotas, já à época da fundação do Anglo, era uma cidade com longa trajetória, uma das mais ricas do Rio Grande do Sul, em decorrência da economia gerada desde o século XVIII pela indústria saladeril. Quando o Anglo fechou, houve desemprego e impacto econômico, mas a cidade tinha outras fábricas, inclusive frigoríficos e matadouros menores, capazes de absorver parte da mão de obra e dos prejuízos que a saída destas fábricas provocam, invariavelmente.

Fray Bentos, ao contrário, nasceu praticamente junto com a LEMCO e teve seu 
desenvolvimento atrelado a essa indústria. O fechamento do Anglo impactou fortemente tanto a economia como o desenvolvimento social da cidade. Cidade e indústria se confundiam e, naturalmente, a crise gerada pelo cessar das atividades do Anglo foi muito maior do que em Pelotas.

A grande diferença entre os dois antigos frigoríficos na atualidade, além das atividades desenvolvidas nos espaços fabris, está relacionada aos prédios remanescentes (Fig. 10 e 11). Enquanto em Fray Bentos o conjunto se encontra preservado em sua integridade, em Pelotas alguns edifícios foram mantidos. Sobre o Frigorífico Anglo del Uruguay existe uma farta documentação, como já dito anteriormente, tanto em Fray Bentos, no Museo de la Revolución Industrial, quanto em Montevidéu. No lugar, além dos edifícios, há a paisagem inalterada, as máquinas, equipamentos, mobiliário, documentos, fotografias. Em Pelotas, ao contrário, há o esforço deste projeto em reunir fotografias recentes, sobraram alguns prédios, a paisagem e a memória de ex-trabalhadores.

Em ambos sítios, reconhece-se uma paisagem industrial, fortemente vinculada com a indústria e seu entorno. A ocupação dos territórios, com as indústrias, os bairros operários próximos aos locais de trabalho ${ }^{9}$, os cursos de água, conformam uma cultura de patrimônios materiais e imateriais, remanescente na memória de muitas pessoas. 0 trabalho de patrimonialização desse bem parte de uma vontade de memória, que, coletivamente se afirma de muitos modos.

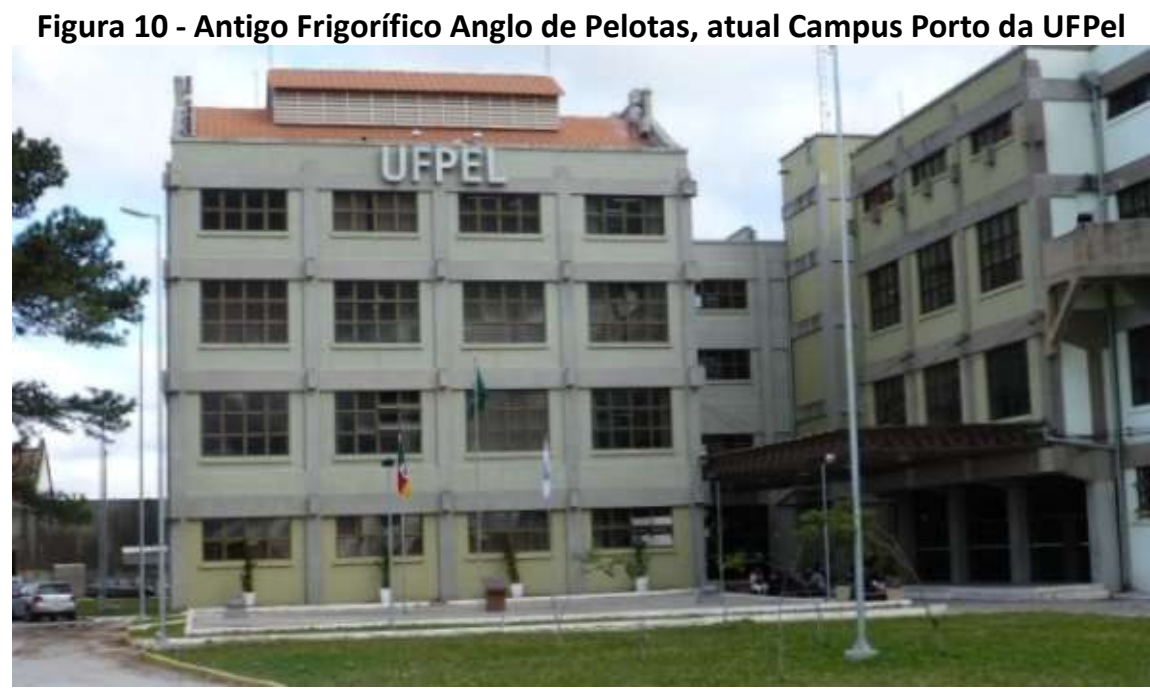

Fonte: Fotografias de Ubirajara Buddin Cruz, 2013. Acervo do autor

\footnotetext{
${ }^{9}$ Convém ressaltar que, diferentemente de Fray Bentos, em Pelotas a iniciativa do bairro não partiu do Anglo. Ele surgiu espontaneamente ao lado da indústria, como uma alternativa de proximidade do trabalho.
} 
Figura 11 - Antigo Frigorífico Anglo del Uruguay, atual Museo de la Revolución Industrial

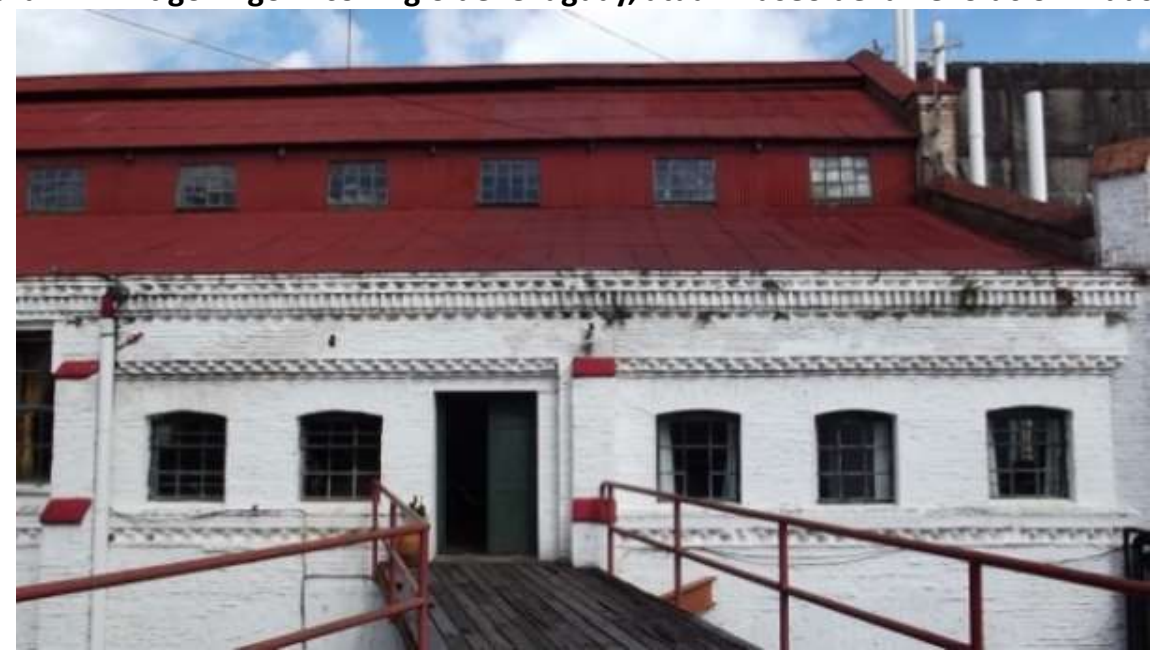

Fonte: Fotografias de Ubirajara Buddin Cruz, 2013. Acervo do autor

\section{FOTOGRAFIA, MEMÓRIA E PATRIMÔNIO INDUSTRIAL}

Partindo dos pressupostos vistos anteriormente sobre os dois frigoríficos, o que se propõe é utilizar a fotografia como elemento de suporte para a memória e ajudar no reconhecimento e preservação do patrimônio industrial, no caso de Pelotas. Como observado em trabalho anterior, "mesmo que em momento algum se tenha esperado que a fotografia trouxesse o passado de volta, ou levasse o espectador a ele" (MICHELON, 2013, p. 59), a possibilidade de reconhecimento dos espaços é esperançosa e, mesmo que não se tenha garantias de resultado, observa-se nelas, as fotos, o melhor potencial de aproximação possível em um campo fraco de outras formas de documentação.

Até 2008, quem chegava ao Anglo, já ocupado pela UFPel, ainda conseguia ver exatamente como era no período produtivo, os prédios da administração e laboratórios à direita (Fig. 12) e, à esquerda, o primeiro, onde ficava a casa de força (ou casa das máquinas) e o outro, onde houve uma lavanderia, quando os uniformes deveriam, por exigência sanitária, permanecer na indústria (Fig. 13), depois que foi proibido o uso do uniforme fora da fábrica. Embora bastante danificados pela ação do tempo e abandono, eram reconhecíveis. 
Figura 12- Prédio da administração e laboratórios

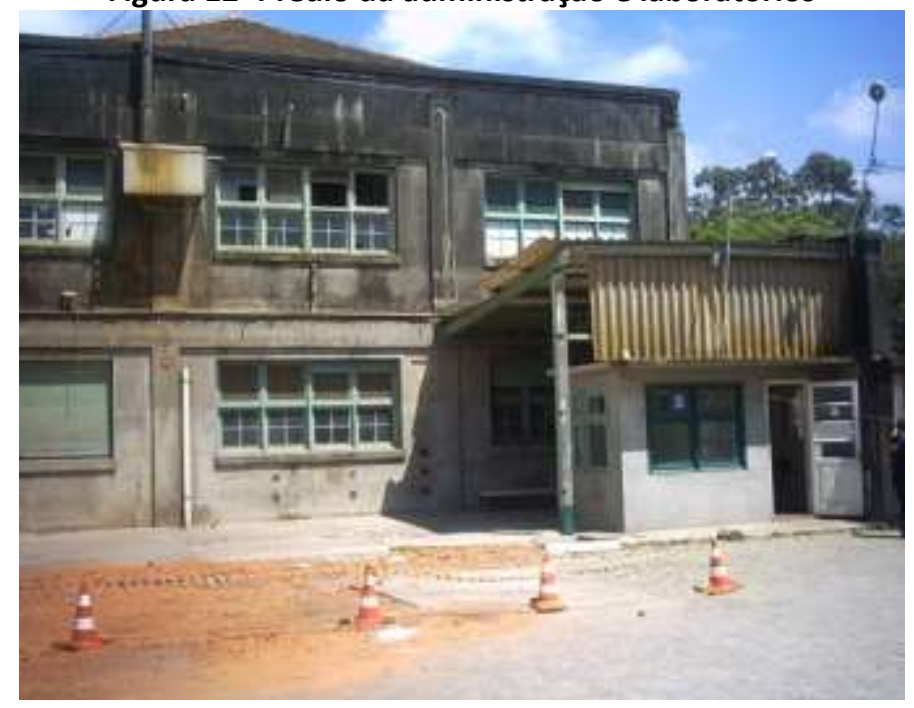

Fonte: Fotografias de Ubirajara Buddin Cruz, 2008. Acervo do autor

Figura 13 - Casa de força e lavanderia

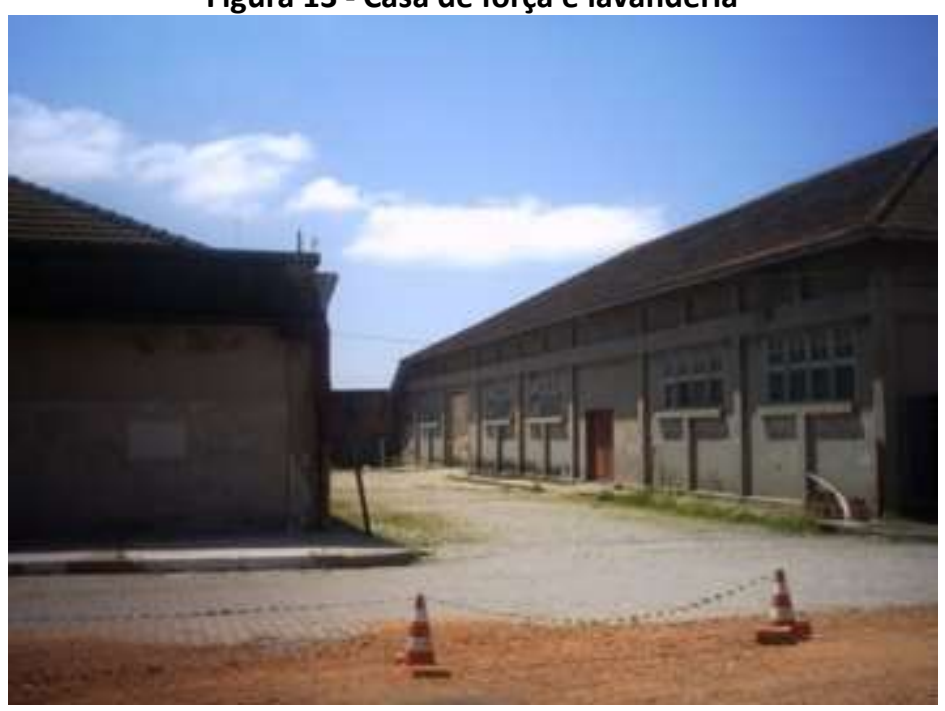

Fonte: Fotografias de Ubirajara Buddin Cruz, 2008. Acervo do autor

Quando a administração da UFPel criou a biblioteca para o novo campus, escolheu os dois prédios à esquerda, construindo um anexo de vidro unificando-os, o que alterou a referência visual do edifício, principalmente depois da pintura feita no prédio reformado (Fig. 14). Ao apresentar a fotografia da biblioteca à Sra. Maria Luiza Griffiths ${ }^{10}$, essa relatou que não conhecia o prédio, que não havia na época em que trabalhou no Anglo.

${ }^{10}$ Entrevista com a Sra. Maria Luiza Griffiths, que trabalhou na Recepção entre 1975 e 1976 , em 25 set. 2015. 


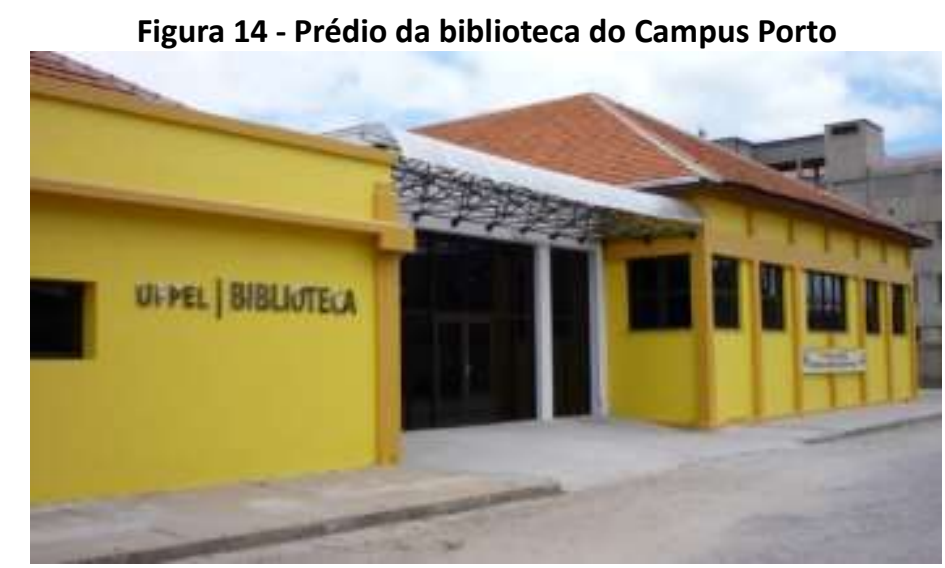

Fonte: Fotografia de Ubirajara Buddin Cruz, 2009. Acervo do autor

Não se teve acesso a nenhuma fotografia do trabalho dentro do frigorífico de Pelotas no seu período produtivo. Nesse sentido, os bancos de imagens obtidos na Argentina e no Uruguai foram o elemento distinto no método de estudo comparativo, uma vez que os espaços e as atividades de trabalho eram muito semelhantes (Fig. 15). Fora isso, conta-se com fotos atuais dos sítios estudados. A semelhança da trajetória das duas indústrias acaba quando do encerramento das atividades de trabalho. A diferença é tão brutal que Fray Bentos teve seu reconhecimento pela Unesco, com a Paisaje Cultural Industrial Fray Bentos inserida na lista de Patrimônio Cultural da Humanidade, enquanto em Pelotas alguns poucos prédios resistiram. Embora bastante descaracterizados em seus interiores, do lado externo mantém sua imponência e é possível reconhecer que ali foi uma grande indústria.

Figura 15 - Trabalhadores no Frigorífico Anglo del Uruguay, Fray Bentos

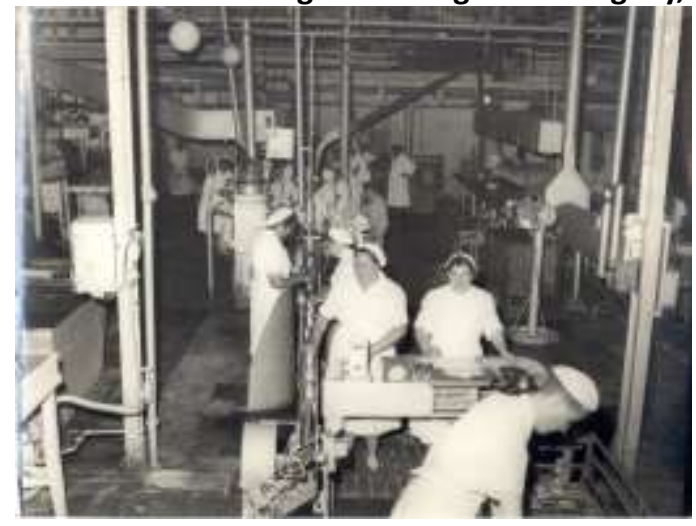

Fonte: Archivo de la Imagen del Sodre, Montevideo, Uruguay

A massiva destruição das antigas cidades europeias durante a Segunda Guerra Mundial foi o fato detonador de uma ação que se consumou na década de 1950 por meio da constituição do conceito e do significado de Patrimônio Industrial. Enquanto monumentos ou cidades inteiras eram erguidas das ruínas, as fábricas, poupadas ou não, faziam perceber o seu valor informacional e simbólico como detentoras de vestígios de processos produtivos e de formas como expressão da obsolescência dos 
métodos tradicionais do trabalho, que sucumbiam às tecnologias mais avançadas. Assim, tornavam-se obsoletos prédios, máquinas, formas e processos da produção industrial. O conceito, em si, tomou forma no texto da Carta de Nizhny Tagil (2003) que define que o patrimônio industrial:

[...] se compone de los restos de la cultura industrial que possen un valor histórico, tecnológico, social, arquitectónico o científico. Estos restos consisten en edificios y maquinaria, talleres, molinos y fábrica, minas y sitios para procesar y refinar, almacenes y depósitos, lugares donde se genera, se transmite y se usa energía, medios de transporte y toda su infraestructura, así como los sitios donde se desarrollaran las actividades sociales relacionadas con la industria, tales como la vivienda, el culto religioso o la educación. (CARTA DE NIZHNY TAGIL SOBRE EL PATRIMONIO INDUSTRIAL, 2003).

Para Ferreira (2009), a noção do patrimônio industrial nos remete a ideia de uma inversão de funções e sentidos: o que antes era um lugar de trabalho se transforma em lugar para a memória. Era frequente que antigos sítios fabris fossem vistos como vestígios de atividades que tinham entrado em declínio e abandono e, sendo assim, sem importância alguma.

Pierre Nora nos diz que a curiosidade pelos lugares onde a memória se cristaliza e se refugia está ligada a um momento particular da história. O sentimento de continuidade torna-se residual aos locais, o que faz com que locais de memória existam porque não há mais meios de memória $(1981$, p. 7). Ainda que o conceito de Nora tenha se construído sobre a observação dos monumentos nacionais, incluídos nesses, as datas, os festejos e as celebrações, sua percepção sobre o fenômeno memorial contribui na compreensão de como se dá a conversão do lugar fabril para o patrimônio industrial:

a memória se alimenta de lembranças vagas, telescópicas, globais ou flutuantes, particulares ou simbólicas, sensível a todas as transferências, cena, censuras ou projeções. A memória instala a lembrança no sagrado, a história a liberta, e a torna sempre prosaica. A memória emerge de um grupo que ela une, o que quer dizer, como Halbwachs o fez, há tantas memórias quanto grupos existem; que ela é múltipla e desacelerada, coletiva, plural e individualizada. A história, ao contrário, pertence a todos e a ninguém, o que lhe dá uma vocação para o universal. A memória se enraiza no concreto, no espaço, no gesto, na imagem, no objeto (NORA, 1981, p. 9).

Reporta-se à compreensão de Halbwachs quando enuncia que "as memórias individuais são pontos de vista sobre a memória coletiva" e, "enquanto seres sociais mesmo que outras pessoas não estejam fisicamente presentes, nunca estamos sós" (1990). Este co-presença é apreensível nos relatos dos depoentes do Anglo que deixam 
elementos para que se apreenda as formas de trabalho dentro dos frigoríficos. A reiteração de alguns aspectos da convivência neste ambiente reforçam o compartilhamento das memórias que presentificam e, não raro, idealizam a indústria do passado. Dito de outra forma entende-se que, na medida em que o sujeito recorda a partir dos lugares que ocupa nas instituições às quais pertence (neste caso específico, o lugar de trabalho), também a memória coletiva sobre essa indústria é construída e rememorada, a partir das lembranças e das trajetórias dos sujeitos que dela fizeram parte (HALBWACHS, 1990).

Nesse estudo, a relação entre os depoimentos de ex-operários e outras pessoas que exerceram atividades diversas na fábrica ou estiveram relacionadas a ela por familiares, todos detentores de memórias diretas ou indiretas sobre o lugar, e as fotografias da indústria, indicam a possibilidade de uma rede de informações que se reafirmam ou contradizem mas, em ambos os casos, por concordância ou conflito, esboçam a dimensão de sentidos possíveis desse cenário de relações humanas. Mesmo que vacilantes, as memórias, aliadas ao uso das fotografias, formam o caminho disponível para que a trajetória dessa indústria possa ser compreendida, uma vez que outros documentos não são disponíveis. As alterações feitas nos edifícios os descaracterizaram de tal modo que já não mais se fazem reconhecíveis pelos antigos trabalhadores que o visitam. Os espaços foram divididos, ergueram-se paredes e outras foram suprimidas, surgiram novos condutores, como um corredor de salas de aula com janelas, onde antes funcionavam as câmaras frias (Fig. 16) e, portanto, não havia abertura alguma. Como a fábrica perdeu suas referências para dar outro uso ao edifício, também parte dos atuais usuários do campus desconhecem o que foi o local. Nesse ponto, as fotografias mostram suas possibilidades como suporte de memória e como ferramenta para ajudar a a compreender o passado industrial do lugar. Há, portanto, pela fotografia, uma possibilidade memorial para este antigo lugar de trabalho.

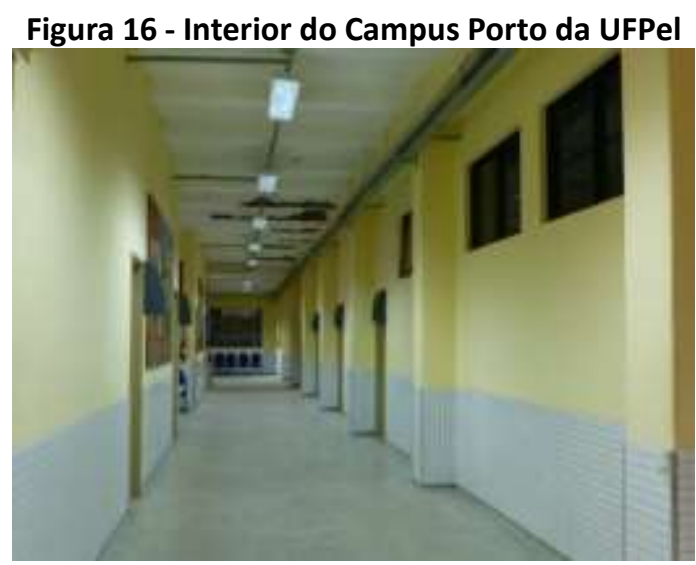

Fonte: Fotografia de Ubirajara Buddin Cruz, 2015. Acervo do autor 


\section{OS OBJETIVOS ATINGIDOS OU MODIFICADOS: RESULTADOS E}

\section{DISCUSSÃO}

Arrolam-se os principais objetivos que conduziram esse trabalho, evidenciando os métodos e discutindo os resultados obtidos.

A revisão bibliográfica sobre os frigoríficos estrangeiros na América do Sul durante o século $X X$ descreve história semelhante nos três países, com formação de trusts eventuais. O único estudo sobre o Frigorífico Anglo de Pelotas, que antecedeu o primeiro levantamento feito pela autora do relatório em 2012, foi publicado por Janke, em 2011, ainda que tendo sido realizado três anos antes; sobre o Frigorífico de Barretos, destaca-se o trabalho de Araújo, em 2003. Também este aspecto faz contraste entre os frigoríficos brasileiros com os uruguaios já que desse se destacam, entre outros os estudos de Campadónico, com muitas publicações das quais se cita o artigo de 2000; Douredjian e Taks, ambos em 2009. O jornal El Observador publicou em 2011 uma revisão sobre a história do comércio e indústria do país e, evidente, destacou-se a indústria da carne como ponto de fulcral importância na economia uruguaia desde o século XIX. Fray Bentos ocupou parte significativa da publicação. Ainda, um artigo de Sena, publicado em 2012 discorre sobre elementos que circunstanciaram a trajetória da indústria da carne, sobretudo no que concerne à pecuária em território uruguaio. Ainda, foram significativos para compreender a trajetória social do trabalho nos frigoríficos, os estudos de Valdéz e Perinelli, ambos de 2007 e de Medrado em 2008. Como para o capital estrangeiro, as fronteiras eram diluídas, a história do Anglo na Argentina também foi explicativa dos mecanismos de origem e fim que se colocavam em ação cada vez que surgia ou encerrava uma unidade. O grupo estado-unidense que tinha como bandeira o Swift foi estudo de vários pesquisadores (AGUIRRE, 1958; BUXEDA, 1983; LOBATO, 2007; ROLDÁN, 2008) sistematizando as formas de trabalho e convivência nesses frigoríficos. O levantamento de estudos sobre patrimônio industrial no Brasil estendeu-se até setembro de 2014.

A localização dos depoentes ocorreu no primeiro semestre de 2014 e partiu de um grupo que foi sendo indicado pelos primeiros depoentes ou localizado nos projetos relacionados. A maioria é constituída por pessoas ainda residentes na Vila da Balsa, agrupamento de casas que se formou e ao longo do tempo cresceu, na área adjacente ao Frigorífico. $O$ instrumento de entrevista caracterizou-se por ser um roteiro semiestruturado que privilegiou informações sobre o espaço, as formas de trabalho e a sociabilidade no frigorífico. Esse instrumento foi construído entre os meses de novembro de 2013 e fevereiro de 2014 e já aplicado nas primeiras entrevistas ocorridas ainda em 2013. As entrevistas estenderam-se ao longo dos anos de 2014 e 2015 e com 
elas a localização de fotografias. A expectativa em localizar fotografias sobre os locais de trabalho dentro do frigorífico foi frustrada à medida que avançava com as entrevistas. A solicitação de imagens deparava-se com a observação de que não se fazia fotografias no local de trabalho. Os motivos apresentados foram diversos: não se tinha equipamento, não havia tempo, não havia permissão ou, simplesmente, não havia o porquê fotografar. Como o frigorífico fechou no início dos anos 1990 o processo usual ainda era o fotoquímico e o equipamento para o registro ainda era a câmera e mesmo a mais compacta empregava como suporte o filme fotográfico, que sempre apresentou custo. Os usos e funções sociais da fotografia só iriam mudar, essencialmente, com a consolidação do processo digital incorporado a outros equipamentos, como o celular. Portanto, o fraco atingimento desse objetivo apresenta inflexões sobre o tempo da ocorrência do trabalho nesses frigoríficos que merece reflexão por parte do presente trabalho.

Justamente diante de tal dificuldade é que a identificação das fotografias, especialmente aquelas geradas entre a venda do complexo para a iniciativa privada da cidade, em 1993 e a aquisição pela Fundação Símon Bolívar, em 2006, inclusive nos meses que antecederam o início das obras de adaptação, em 2007, fez-se um método importante. Para tal identificação foram empregadas as entrevistas e o estudo comparativo com os arquivos uruguaios e argentinos, localizados em Montevideo, Fray Bentos e Buenos Aires. Os últimos vestígios das câmaras frias, que documentavam as técnicas construtivas da conservação pelo frio, com o ápice da tecnologia disponível nos anos 1940, foram suprimidos em 2014, portanto, durante o projeto ainda foi possível registrar o local e detalhes das técnicas empregadas. Com a ajuda de alguns depoentes, foi possível inclusive esclarecer o histórico do lugar onde hoje se encontra o Memorial do Anglo. O engenheiro responsável pelas obras do terceiro e quarto andar dos bloco $B$, onde hoje funcionam algumas faculdades, relatou que ao chegar para o cumprimento da função encontrou o piso 1 e 2 já alterados. No segundo, onde havia a sala da abates, foi construída uma laje que dividiu a altura desse espaço, gerando o terceiro piso. Os trilhos do teto que suportavam o sistema para içar e transportar a carcaça do boi abatido, foram mantidos, mas tapados com o reboco do teto. Nas salas de processamento, que eram isoladas para a manutenção da temperatura baixa, foram abertas janelas, foram retirados os cerâmicos brancos do chão e teto e foram divididas. Destaca-se que o projeto arquitetônico e o planejamento dessas obras não foram localizados na UFPel.

O tratamento das fotografias em suporte físico adquiridas para a Coleção Anglo que foi depositada na Fototeca Memória da UFPel foi feito, no entanto, a maioria do acervo é digital. Mesmo as fotografias localizadas com depoentes e colaboradores 
foram reproduzidas originalmente e manteve-se o original com os proprietários. A opção em não solicitar a fotografia original deveu-se ao fato de que o tratamento dos exemplares demandaria recursos materiais e humanos não disponíveis.

No entanto, a sistematização da informação das fotografias adquiridas em suporte físico ou reproduzidas em arquivo eletrônico era feita imediatamente. 0 método empregado foi a ficha de inventário no qual a informação obtida é relacionada com a imagem. Os arquivos obtidos dos frigoríficos estrangeiros em Montevideo, Fray Bentos e Buenos Aires limitou-se a organizar essas fontes conforme os dados disponibilizados pelas instituições detentoras dos originais. Já, a digitalização das fotografias foi feita imediatamente à localização das mesmas. A elaboração dos álbuns temáticos foi feita seguindo a formulação de conjuntos temáticos elaborados conforme o intuito da pesquisa: frigoríficos do século XIX, abate de animais em matadouros do século XIX, instalações de processamento da carne e venda de animais no século XIX, vistas aéreas de frigoríficos argentinos e uruguaios, setores dos frigoríficos no século $X X$, comercialização e transporte da carne, sociabilidades, maquinário, vistas gerais da planta fabril, pessoas. Essa divisão temática vai adquirindo subdivisões conforme os temas se constituem dentro destas generalidades. Por exemplo, as fotos do time de futebol do Anglo foram colocadas em sociabilidade, com esta divisão específica. Fotos pessoais, nas quais não se evidencia qualquer referência ao local de trabalho, foram colocadas em Pessoas. Ressalta-se que a maioria dos depoentes eram operários, moradores da Vila da Balsa, que subsistiam com o salário mensal ou serviços sazonais e para quem, no período do estudo, a fotografia era um registro caro, portanto, pouco frequente.

As fotografias realizadas pelos autores desse relatório foram tomadas nas visitas técnicas, registro dos edifícios e nas entrevistas. As fotografias das entrevistas poderão ser usadas quando da disponibilização das entrevistas se autorizadas pelos depoentes. Optou-se por gerar documentação fotográfica e não proceder às filmagens, tendo em vista que os recursos disponíveis para filmagem não eram profissionais. 0 equipamento usado na documentação fotográfica apresentava qualidade de registro desejável. As fotografias geradas que constituíram os conjuntos mais importantes nas duas visitas técnicas foram: documentação completa do sistema patrimonial de Fray Bentos, documentação das câmaras frias do extinto Frigorífico Anglo de Pelotas e documentação do remanescente da planta industrial de Pelotas. A edição dos conjuntos fotográficos gerados quantificou os registros em: 1. Complexo industrial Fray Bentos: 652 fotografias; câmaras frias Anglo Pelotas: 167 fotografias; remanescente da planta industrial do Anglo Pelotas: 338 fotografias. Esses três conjuntos formam os grupos que foram comparados, sobretudo no Bloco B do atual campus Anglo da UFPel, 
no qual se encontravam, antigamente, as câmaras frias e no qual se encontra o Memorial do Anglo.

A realização das entrevistas foi etapa iniciada logo após a localização dos depoentes. O contato anterior à entrevistas implicava na apresentação do objetivo do trabalho e no agendamento da entrevista. Sempre que possível, era feito o convite para que o depoente fosse ao campus Anglo da UFPel, para que lá se procedesse à entrevista. Foram realizadas oito entrevistas com oito depoentes do mês de dezembro de 2013 a agosto de 2015. Mais entrevistas ainda serão realizadas.

Todas as entrevistas foram transcritas e os depoentes autorizaram suas publicações. A transcrição foi feita primeiramente direta, com posterior supressão de repetições ou falhas da gravação e adequada para a apresentação posterior ao depoente. A revisão foi feita em três momentos: 1) revisão da transcrição literal, na qual foram feitas supressão de falhas ou repetições desnecessárias e outros aspectos que fugiram ao escopo da entrevista; 2) revisão do depoente: a primeira versão foi apresentada aos depoentes e dos seus comentários foram feitas alterações indicadas, em geral consistindo em alguma correção na informação. 3) revisão após aprovação do depoente: consistindo na melhor adequação possível à linguagem vernacular sem mudança de conteúdo. Considerou-se a versão revisada a última e a que foi utilizada para a análise.

Do conteúdo das entrevistas, foram pontuadas as respostas que permitiram organizar esquemas de descrição dos espaços e atividades laborais. Sob esse aspecto, foi possível elaborar um esquema da planta industrial na sua última fase, correspondente à década de 1980 e 90. Alguns aspectos, como o atendimento ao abate humanitário, que correspondia à substituição do golpe de marreta pelo disparo com a pistola pneumática, vigente no Brasil somente a partir de 2000, como instrução normativa ministerial, foi eventualmente praticado nos últimos anos de funcionamento do matadouro. No entanto, esse dado é apresentado de modo diverso pelos depoentes. Os comparativos entre as fotografias obtidas em Fray Bentos e aquelas feitas em 2007 no Anglo Pelotas, permitiram a exata localização da rampa dos animais, as seringas, o cercado do golpe e a área de sangria após o atordoamento. A maior dificuldade, dadas as alterações no edifício ainda é a localização do trânsito entre a área de processamento e as câmaras frias. Foi possível localizar a área de produção do charque com secagem ao sol e as mudanças no depósito de graxas, de couros e de secagem do sangue. Foi possível localizar a área de lazer da diretoria (não mais existente), o refeitório, a sala das máquinas, as oficinas, a lavanderia e vestuário e os laboratórios. 
Com base nessas informações, foi possível modelar em 3D do espaço das câmaras frias do Frigorífico Anglo, supondo a sua localização completa. A modelagem será disponibilizada no site logo que houver indicação mais segura sobre o número de câmaras refrigeradas e de congelamento.

As exposições virtuais das fotografias dos Frigoríficos Anglo de Pelotas e Fray Bentos constitui uma das primeiras decisões, tão logo se entendeu que o Memorial do Anglo deveria ser o vetor fundante da divulgação dos resultados do trabalho. No site do Memorial, as fotografias históricas, obtidas no Uruguai e Argentina, estão disponíveis e apresentam-se como formas de exposição das coleções sistematizadas no próprio Memorial, onde há um display que contempla e complementa a exposição de longa duração. Em uma apresentação de 55 minutos, textos e imagens se sucedem no display de modo a expandir a informação contida no espaço expositivo. A autorização de uso das fotografias obtidas nos países vizinhos não possibilita a veiculação das fotos em sites estrangeiros.

Foram feitas duas visitas técnicas ao Sistema Patrimonial Industrial Anglo em Fray Bentos, uma em 2013 e outra em 2014. Nas duas, foram geradas as documentações fotográficas que registram o complexo industrial completo de Fray Bentos. Em ambas, concluiu-se que para o levantamento de documentos será necessário um trabalho específico, com uma equipe de no mínimo dois pesquisadores com permanência na cidade por um período inicial de 10 dias para pré-inventário e um período posterior, a confirmar a duração, conforme levantamento anterior, para reprodução digital de parte do acervo relativa à unidade de Pelotas. Foi possível com estas duas visitas, realizar o levantamento de dados e inventário de aspectos a serem comparados com o Frigorífico Anglo de Pelotas, por meio das fotografias.

O estudo comparativo entre as unidades do Frigorífico Anglo de Pelotas e de Fray Bentos foi desenvolvido sobre as fotografias localizadas nos arquivos das instituições já citadas, em Montevideo, Fray Bentos e Buenos Aires e na documentação gerada sobre o complexo uruguaio durante as visitas técnicas. $O$ estudo permitiu compreender a planta industrial pelotense e, sobretudo, a dinâmica desses espaços de trabalho, regulados pelos princípios das atividades laborais do capital estrangeiro, de matriz inglesa que, sob muitos aspectos, equalizavam as formas de convivência e interação entre operário e indústria. No entanto, quando se relatam os resultados da pesquisa, é necessário registrar que o empreendimento demanda continuidade para verificação das mudanças ocorridas entre o período da fundação do Frigorífico de Pelotas até a década de 1970, quando se registram significativas alterações nas áreas de abate e processamento. 
Ainda relativo ao estudo comparativo faz-se a análise do processo de entrevistas visando verificação dos aspectos comparados. No presente estudo, o escopo da investigação foi compreender o espaço do Frigorífico Anglo de Pelotas, ativado como unidade complementar à demanda de alimentos para as tropas aliadas na Europa, durante o Segundo Grande Conflito e o seu impacto na formação de grupos sociais que poderiam esclarecer a cidade operária e industrial que pulsa sob a outra cidade eleita e reiterada pelo passado presentificado nos monumentos históricos da zona central e das charqueadas. Sob o primeiro aspecto, as entrevistas foram determinantes, ainda que diante da topografia alterada decorrente do processo de adequação dos edifícios, surgiram incertezas não verificadas. $O$ segundo aspecto demanda desdobramentos que seguem para além das entrevistas já feitas.

Retoma-se o já exposto no início deste capítulo do relatório sobre o site do projeto, reafirmando a decisão de que o trabalho a ser apresentado deveria situar-se no Memorial do Anglo, entendendo-o como o lugar no qual os resultados da pesquisa deveriam ser disponibilizados à comunidade, acadêmica ou não. O Memorial foi o investimento fulcral dos projetos que se dedicaram a valorizar, por meio da atribuição de novos sentidos, o passado do lugar, hoje ocupado pelo campus Anglo da Universidade Federal de Pelotas. Como lugar físico, de visitação, plenificado pela informação contextualizada, o Memorial passou a ser um endereço no qual se encontra disponível o histórico do lugar. Os desdobramentos desta decisão reverberaram na política de proteção ao patrimônio cultural da UFPel, na redenominação do campus Porto e no projeto das galerias do Memorial do Anglo, a serem desenvolvidos na conclusão desse relatório.

Igualmente, os resultados impactaram na decisão pelo recolhimento de depoimentos, informações e imagens através do site. No momento, o site do Memorial não comporta a condição técnica de realizar este método de aproximação do público com o trabalho desenvolvido pelo projeto. Há uma possibilidade similar observada no formato utilizado pelo blog do Frigorífico Anglo de Barretos ${ }^{11}$. No entanto, não cumpriria com o objetivo geral de fornecer informações sobre o local no passado e

\footnotetext{
11 Intitulado "Bairro Frigorifico e seus moradores" o blog tem como finalidade, conforme consta na sua página inicial "resgatar rmemórias e fotos dos ex-moradores e funcionários do Frigorífico Anglo de Barretos". A implantação do blog data de 2011 e todos os depoimentos, de julho de 2012, somando 7 ao todo, dentre os quais uma poesia e a postagem de um anúncio do mini-mercado do Frigorífico, datado de 1984, no qual consta um logotipo com o desenho de uma cabeça de boi. O acervo é de Leopoldo da Costa, cujo depoimento se encontra no blog e no qual narra o trabalho de sua vida na fábrica, de aprendiz a diretor. No depoimento é possível identificar o nome de um dos ingleses Sr. Cunningham, que foi gerente no frigorífico de Goiania e que foi citado muitas vezes pelos depoentes locais. Sabe-se, por fontes que foi o presidente-gerente do Frigorífico de Pelotas, desde a sua inauguração em 1942. Por um cálculo impreciso, com base no depoimento, este fato ocorreu no final dos anos de 1960, portanto, é possível que este gerente tenha saído de Pelotas por volta de 1970. Outras informações desse depoente conferem com relatos da presente pesquisa.
} 
possibilidades de verificação. Desse modo, pretende-se que ao final do projeto se possa ter outra estratégia para captar depoentes não inseridos na rede de informantes que se estabeleceu durante o projeto.

Portanto, também não se aplicaram os indexadores para a identificação de dados do espaço virtual, embora se tenha na organização do banco de dados de imagens, a possibilidade de utilizar os mesmos como agrupamentos de conteúdos correlatos. Assim: nas câmaras frias do Anglo de Pelotas é possível estabelecer como indexadores: 1. localização das câmaras frias; 2 . número de câmaras refrigeradoras e de congelamento; 3 . dimensões e sistema de refrigeração; 4 . atividades realizadas nas câmaras frias; 5 . produtos estocados nas câmaras frias; 6 . uniformes e sistemas de proteção; 7. depoimento sobre o trabalho nas câmaras frias. Sobre o remanescente da planta industrial do Anglo Pelotas: 1. Edifícios; 2. Setores nos edifícios; 3. Mobilidade entre os edifícios; 4 . Chaminé; 5 . Sala de abate; 6 . Salas de processamento da carne; 7. Sala de cozimento de carnes; 8. Mercado; 9. Sala de Conservas; 10. Graxaria. Por fim, para conseguir apreender a realidade social do trabalho nessa unidade, seria necessário que os depoimentos fossem livres e não partissem de indexadores diretivos da memória.

Projeta-se que o perfil do usuário poderá se manter equivalente ao dos depoentes arrolados, no entanto, como a entrevista semi-estruturada orienta o conteúdo da entrevista em direção aos objetivos, entende-se que a ocorrência de depoimentos no site deverá ser estimulada ou induzida, para a obtenção de depoimentos mais narrativos.

\section{CONCLUSÕES: O MEMORIAL DO ANGLO DE PELOTAS E OS DESDOBRAMENTOS DA PESQUISA}

A proposta desse projeto já partiu de um trabalho que entendia como sendo necessária a constituição de um espaço para referenciar a história do extinto frigorífico Anglo de Pelotas, no presente, ocupado pela UFPel e, internamente, desalojado de evidências da sua natureza original. As intensas modificações que se operaram internamente, em parte pela urgência com que foram feitas, acabaram favorecendo a permanência de alguns vestígios do que foi esse espaço industrial e de trabalho. A instituição de um espaço físico para a memória do local tomou como exemplo o que foi feito em Fray Bentos, com a instituição do Museo de la Revolución Industrial. Embora sejam grandes as diferenças entre os dois casos, a ideia de musealização de parte do espaço da fábrica é expressão do entendimento de que as referências memoriais 
demandam ser enunciadas a partir de um locus físico. O caso de Fray Bentos, que manteve a configuração das fábricas que constituem hoje, o sistema patrimonial, foi como uma enciclopédia de imagens onde o Anglo de Pelotas pode encontrar elementos explicativos do seu lugar. Assim, o espaço dedicado ao Memorial do Anglo (Fig. 17) se configura como proposição simbólica de ritualização e valorização do passado. Assim, a implantação do Memorial organizou e direcionou a proposta dessa pesquisa.

O estudo expográfico do Memorial se deparou com o desafio em apresentar o conteúdo sem substratos referenciais, já que os arquivos visuais localizados registravam a fábrica já fechada. O conteúdo era, necessariamente, a trajetória do frigorífico durante seus cinquenta anos de funcionamento e os setores de trabalhos, cujos limites e evidências se perderam na reforma. Afirmou-se, por meio dos depoimentos dados por ex-operários, no local da fábrica, incertezas advindas da supressão de espaços ou da construção de elementos que os modificaram. Não apenas, mas especialmente, a área do abate de bovinos e o percurso do processamento do animal abatido foram de tal forma diluídos que, nem estando no local exato, era possível reconhecer o ambiente antigo. A altura da antiga área promoveu que a reforma gerasse dois andares onde antes havia um. Os trilhos do teto para a movimentação aérea da carcaça foram tapados, dada a dificuldade ou impossibilidade em tirá-los. A intervenção não desconsiderou o nível de proteção do bem e não alterou os contornos do prédio, ainda que tenha suprimido a condição de isolamento térmico do edifício ao abrir janelas nas paredes cegas da câmara fria.

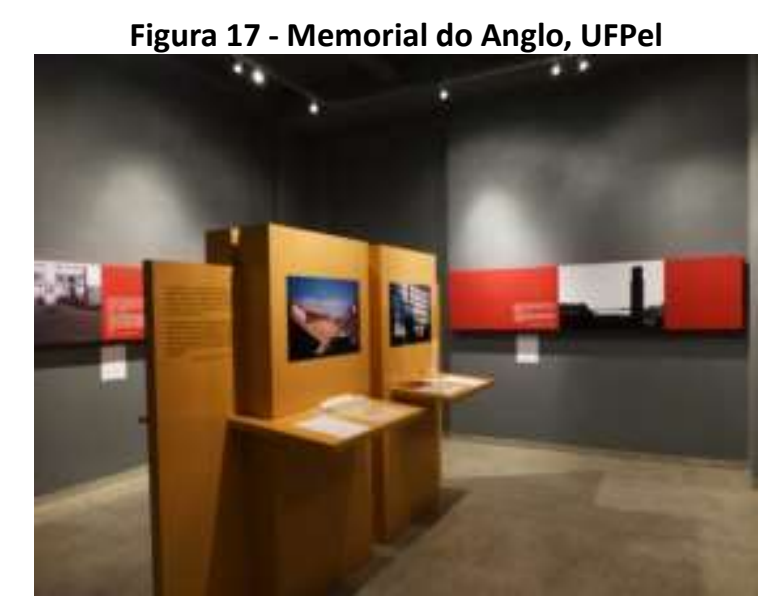

Fonte: Fotografia de Ubirajara Buddin Cruz, 2014. Acervo do autor

Deste modo, apenas no lugar onde há o Memorial revela-se a técnica construtiva das câmaras frias, fazendo-a compreensível ao visitante através das ruínas (Fig, 18). O acréscimo de outros suportes informacionais dentro e no entorno das ruínas objetivou tornar esse fragmento de tempo passado, instituído de sentido, com o 


\section{Romian}

qual as fotografias de Fray Bentos desempenham importante papel, tal como se depreende na informação contida nas fotografias seguintes (Fig. 19, 20, 21). Nessas, entende-se o edifício das câmaras frias do Anglo uruguaio, no qual a tecnologia empregada pouco dista da que foi utilizada em Pelotas.

Por outro lado, entende-se que o projeto logrou atingir algumas metas relevantes: a formação de recursos humanos seja nos duas pesquisas de mestrado que estão sendo desenvolvidas sobre o patrimônio industrial da Universidade Federal de Pelotas, o que implica em proposição para uma nova linha de pesquisa no Programa de Pós-Graduação em Memória Social e Patrimônio Cultural. Também com este tema foi encaminhada a proposta de cooperação científica com a Universidade de Sevilha e o trabalho de inserção social com o estabelecimento de um acordo de cooperação entre esse PPG e a Secretaria Municipal de Educação, para desenvolvimento de uma proposta de educação patrimonial, inicialmente formulada no estudo do patrimônio industrial.

Figura 18 - Mostra da parede da câmara fria no Memorial do Anglo, UFPel

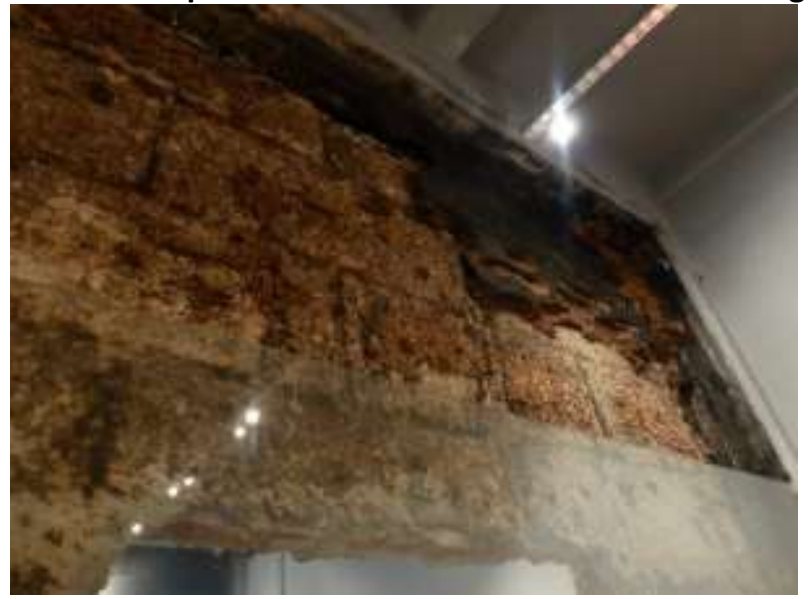

Fonte: Fotografia de Ubirajara Buddin Cruz, 2014. Acervo do autor.

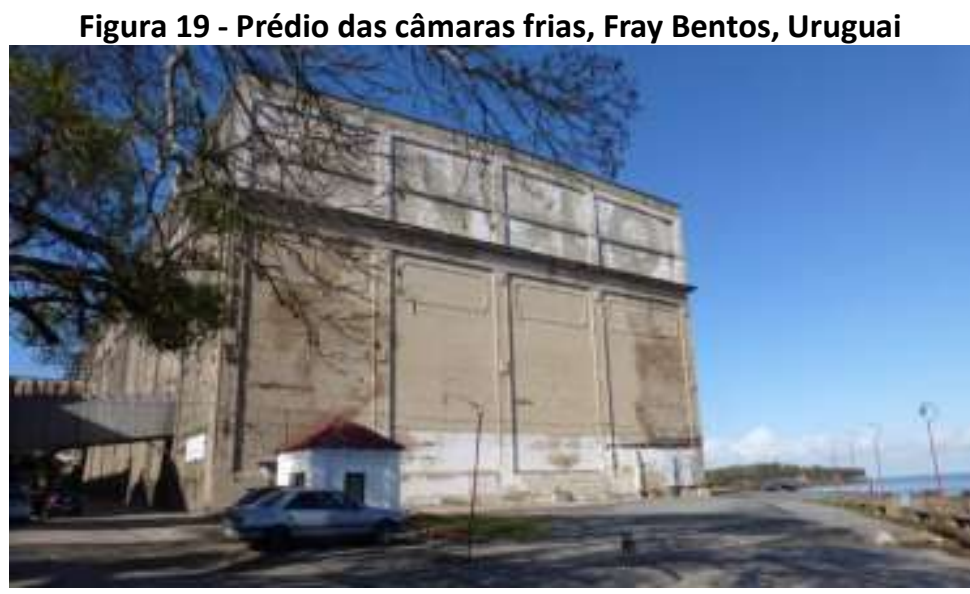

Fonte: Fotografia de Ubirajara Buddin Cruz, 2013. Acervo do autor. 


\section{Revista}

Seus prédios, de largas paredes utilizavam o sistema desenvolvido por Sir John Leslie, de absorção, que utilizava ácido sulfúrico como absorvente e água como refrigerante. As paredes formavam um sanduíche de uma camada de alvenaria de tijolos e concreto, uma de cortiça de aproximadamente 10 centímetros, uma camada central de espuma, outra de cortiça e mais uma de alvenaria.

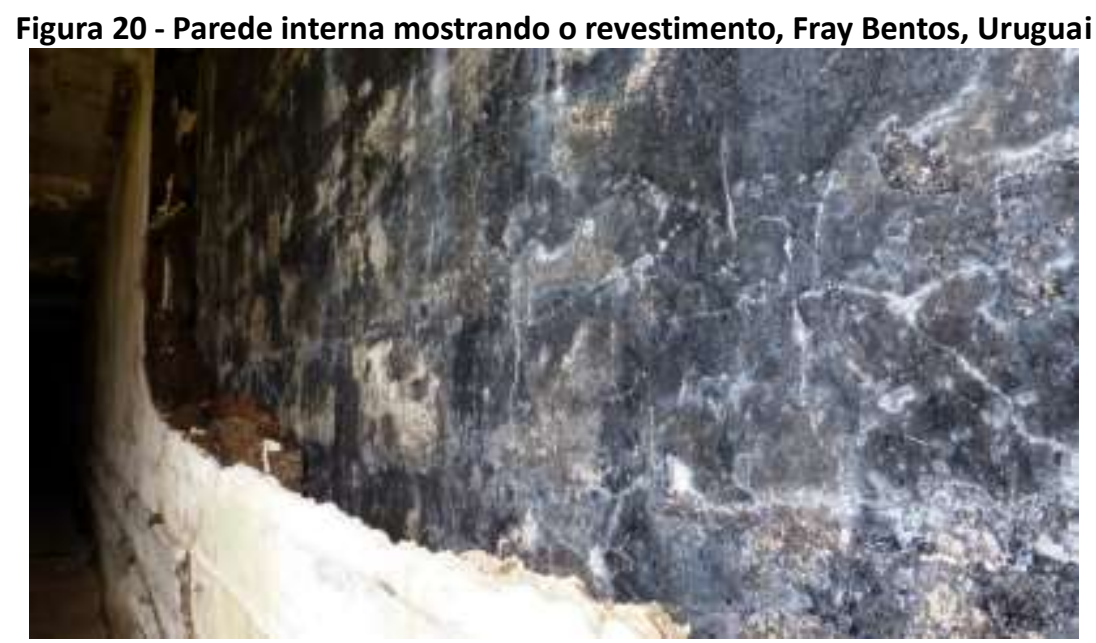

Fonte: Fotografia de Ubirajara Buddin Cruz, 2013. Acervo do autor.

Observa-se a semelhança da técnica construtiva nas mostras das paredes nas fotografias 18, em Pelotas e na 20, em Fray Bentos. Na fotografia seguinte, observamse as nórias, trilhos onde eram suspensas as peças de carne. Em Pelotas este elemento decisivo da arquitetura das salas de abate foi escondido pela reforma.

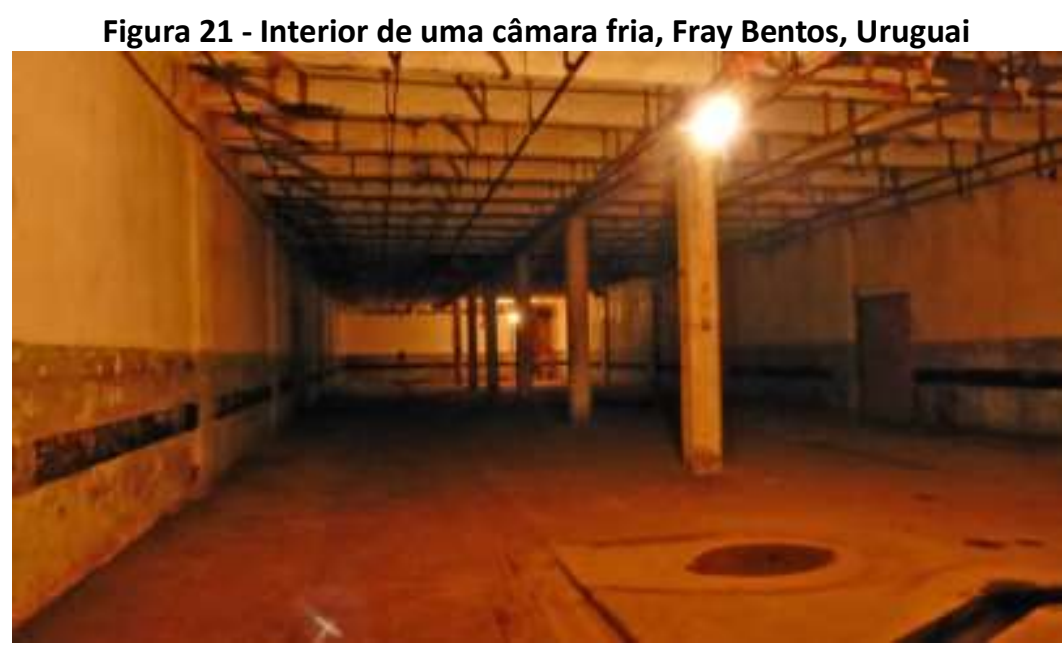

Fonte: Fotografia de Ubirajara Buddin Cruz, 2014. Acervo do autor

O que se pode observar, conclusivamente, é o potencial que a fotografia tem como suporte de memória, mesmo quando não se trata de uma referência direta, ainda assim, faz-se notória a reflexão de Barthes quando sagra a fotografia como um certificado de presença (1980, p. 98). E é através dela que se pretende preencher os vazios da memória sobre o extinto Frigorífico Anglo de Pelotas. 
No entanto, a evidência da proposta de novo sentido ao lugar que tem seu passado silenciado é o fato de que a ocupação dos prédios do extinto frigorífico eram, em 2013, a preservação do que parecia não querer ceder ao fim irreversível, o contorno dos sólidos muros que compunham o conjunto de cinco edifícios. 0 significativo prédio acordado com uma empreendedora foi transformado em uma estrutura semidemolida, sem paredes e aberturas, expressão de um tormentoso abandono, quando o negócio para a construção de um shopping no local foi desfeito. Como o inventário é de conjunto e havia a percepção de que o valor das edificações não estava no seu caráter excepcional ou monumental, nada foi feito enquanto avançavam as obras. No momento em que se instituiu um local para o enunciado da memória da fábrica, as lentes do patrimônio começaram a focar o tempo pretérito de um local pleno de memórias. Aqueles que as tinham passaram a depositá-las e foi se descobrindo um elenco de pessoas que atuava direta ou indiretamente no campus e lembravam, mas não compartilhavam suas lembranças. Assim que em publicação lançada com o levantamento do patrimônio cultural edificado da UFPel em janeiro de 2014, o Anglo apresentava-se listado formando junto com outros conjuntos, o grupo do patrimônio industrial. A disponibilização do trabalho, o desenvolvimento de um projeto de reciclagem de outra área industrial da UFPel e a instituição do Memorial do Anglo conjugou um sistema de valores que foi cercando o bem. Pode-se constatar por fato recente de que o foco já está feito. Um estudo do Núcleo de Gestão de Espaços, da Pró-Reitoria de Planejamento e Desenvolvimento, apresentou uma proposta de nomenclatura e situação dos campus da UFPel, no qual a denominação Campus Porto, inicialmente aplicada ao Anglo, passa a designar o conjunto entre as ruas Álvaro Chaves e Alberto Rosa e nomeia o endereço Rua Gomes Carneiro, número 1, como Campus Anglo da Universidade Federal de Pelotas. O projeto foi aprovado e será implantado em 2016.

\section{REFERÊNCIAS}

AGUIRRE, Manuel A. Romero. Ganaderia argentina: su desarrollo e industrialización. 2. ed. Buenos Aires: Platt, 1958.

BARTHES, Roland. A câmara clara: nota sobre a fotografia. Lisboa: Edições 70, 1980.

BERNARD, Guillermo. Los monopolios y la industria frigorífica. Montevideo: Ed. de la Banda Oriental, 1970. 
BORETTO OVALLE, René. Fray Bentos: patrimonio cultural e industrial: historiografia 18551955. Montevideo: Tradinco, 2014.

BUXEDA, Martín. La indústria frigorífica en el Río de la Plata: (1959-1977). Buenos Aires: Santo Domingo, 1983.

CAMPODÓNICO, Gabriela. El Frigorífico Anglo: memoria urbana y memoria social en Fray Bentos. Disponível em:

<http://www.unesco.org.uy/shs/fileadmin/templates/shs/archivos/anuario2000/7campodonico.pdf>. Acesso em: 21 jun. 2013.

CARTA de Nizhny Tagil sobre el patrimônio industrial. Moscú: [s.n.], 2003.

COSTA, Leopoldo. A história do extrato de carne. Stravaganza, 25 mar. 2011. Disponível em: <http://stravaganzastravaganza.blogspot.com.br/2011/03/historia-do-extrato-de-carne.html>. Acesso em: 16 jun. 2013.

. A história dos frigoríficos no Brasil. Stravaganza. 17 mar. 2011. Disponível em: <http://stravaganzastravaganza.blogspot.com.br/2011/03/historia-dos-matadourosfrigorificosno.html>. Acesso em: 16 jun. 2013.

DOUREDJIAN, Alberto. Sobre inmigrantes y frigoríficos: el Anglo y los trabajadores (1924-1954). Montevideo: Tradinco, 2009.

GUTIERREZ, Ester Judite Bendjouya. Sítio charqueador pelotense. Pelotas: Paisagem do Sul, 2010.

HALBWACHS, Maurice. A memória coletiva. São Paulo: Vértice: Ed. Revista dos Tribunais, 1990. JANKE, Neuza Regina. Entre os valores do patrão e os da nação, como fica o operário: o Frigorífico Anglo de Pelotas: 1940-1970, Pelotas: Cópias Santa Cruz, 2011.

JUSTIPARÁN, Alejandro Héctor; PUEYO, Leandro. El proyecto del frigorífico argentino: Argentina: 1901: capitales nacionales y soberanía. In: Siempre historia. [Buenos Aires], 2010. Disponível em: <http://www.siemprehistoria.com.ar/2010/01/el-proyecto-del-frigorificoargentino-argentina-1901-capitales-nacionales-y-soberania/>. Acesso em: 15 fev. 2015. LAGEMANN, Eugênio. O Banco Pelotense e o sistema financeiro regional. Porto Alegre: Mercado Aberto, 1985.

MICHELON, Francisca Ferreira. Acervos sistematizados e informação disponível: a fotografia sobre o trabalho no Rio Grande do Sul/Brasil. Revista Memória em Rede, v.3, n.8, jan./jun. 
2013. Disponívem em: <http://www.ufpel.edu.br/ich/memoriaemrede/beta-02-

01/index.php/memoriaemrede/article/view/169>. Acesso em: 12 ju. 2013.

. Fotografias para preencher o vazio de memória: arquivos de imagens dos frigoríficos Anglo em Pelotas/Brasil e Fray Bentos/Uruguai. In: SOSA GONZÁLEZ, Ana María; FERREIRA, Maria Letícia Mazzucchi; ASHFIELD, William Rey (orgs.). Patrimônio cultural: Brasil e Uruguai: os processos de patrimonialização e suas experiências. Pelotas: Ed. da Universidade Federal de Pelotas, 2013. p. 59-80.

. Sociedade Anônima Frigorífico Anglo de Pelotas: o trabalho do passado nas fotografias do presente. Pelotas: Ed. da Universidade Federal de Pelotas, 2012.

NORA, Pierre. Entre memória e história: a problemática dos lugares. Projeto História: Revista do Programa de Estudos Pós-Graduados em História, São Paulo, v. 10, p. 7-29, 1981.

PESAVENTO, Sandra Jatahy. República velha gaúcha: charqueadas, frigoríficos, criadores. Porto Alegre: Movimento IEL, 1980.

TAKS, Javier. La clase trabajadora y las obreras del Anglo. Encuentros, [Montevideo], n.6, p.211230, oct. 1999. 